\title{
Late Palaeozoic extensional volcanism along the northern margin of Gondwana in southern Turkey: implications for Palaeotethyan development
}

\author{
Alastair H. F. Robertson ${ }^{1}$. Osman Parlak ${ }^{2,3}$ - Timur Ustaömer ${ }^{4}$ \\ Received: 26 January 2021 / Accepted: 14 May 2021 / Published online: 7 July 2021 \\ (c) The Author(s) 2021
}

\begin{abstract}
The Late Palaeozoic-Early Mesozoic Tethyan development of the Eastern Mediterranean region remains debatable, especially in Turkey, where alternative northward and southward subduction hypotheses are proposed. Relevant to this debate, new whole-rock geochemical data are provided here for early Carboniferous (Late Tournaisian-Late Visean; c. 340-350 Ma) tuffaceous sedimentary rocks within the Çataloturan thrust sheet (Aladağ nappe), eastern Taurides. The tuffs accumulated from evolved alkaline volcanism, variably mixed with terrigenous and radiolarian-rich sediments. In addition, Late Palaeozoic meta-volcanic rocks, c. $150 \mathrm{~km}$ farther NE, within the Binboğa (=Malatya) metamorphics (a low-grade high-pressure unit), are indicative of a within-plate setting. An impersistent geochemical subduction signature in these volcanics may represent an inherited, rather than contemporaneous, subduction influence, mainly because of the absence of a continental margin arc or of arc-derived tuff. Both the Binboğa metamorphics and the Çataloturan thrust sheet (Aladağ nappe) restore generally to the north of the relatively autochthonous Tauride carbonate platform (Geyik Dağ), within the carbonate platform bordering north-Gondwana. The Çataloturan thrust sheet is interpreted, specifically, as a c. E-W, deep-water, volcanically active rift that progressively infilled. Regional geological evidence suggests that melange units (Konya Complex, Afyon zone), Teke Dere unit, Lycian nappes), and Chios-Karaburun melange, E Aegean) accreted to the north-Gondwana continental margin during the late Carboniferous; this was coupled with localised calc-alkaline granitic magmatism (Afyon zone of Anatolide crustal block). We propose an interpretation in which Late Devonian-Carboniferous alkaline intra-plate volcanism relates to extension/rifting along the north-Gondwana margin. In contrast, the melange accretion and granitic magmatism could relate to short-lived late Carboniferous southward subduction that accompanied the diachronous closure of Palaeotethys.
\end{abstract}

Keywords Carboniferous $\cdot$ Rift $\cdot$ Volcanism $\cdot$ Tectonic setting $\cdot$ Gondwana $\cdot$ Palaeotethys $\cdot$ Turkey

\section{Introduction}

Alastair H. F. Robertson

Alastair.Robertson@ed.ac.uk

1 School of GeoSciences, Grant Institute, University of Edinburgh, James Hutton Rd., Edinburgh EH9 3FE, UK

2 Çukurova Üniversitesi, Jeoloji Mühendisliği Bölümü, Balcalı, 01330 Adana, Turkey

3 State Key Laboratory of Geological Processes and Mineral Resources, Center for Global Tectonics, School of Earth Sciences, China University of Geosciences, Wuhan 430074, China

4 Department of Geological Engineering, Faculty of Engineering, İstanbul University-Cerrahpaşa, Büyükçekmece, İstanbul, Turkey
The geological development of the northern margin of Gondwana, in Turkey, during the Late Palaeozoic is critical to an understanding of the wider Tethyan region. Three general (partly overlapping) tectonic models are currently proposed that have implications for the northern margin of Gondwana during Late Palaeozoic time, when Palaeotethys was open, with Eurasia to the north.

Model 1 Palaeotethys existed since Early Palaeozoic (Fig. 1ai) and later, during Devonian-Carboniferous, subducted southwards beneath the northern margin of Gondwana (Fig. 1aii). This process led to the construction of the Sakarya magmatic arc. Southward subduction triggered rifting of a back-arc basin to the south which became the Southern Neotethys during the Triassic (Fig. 1aiii). In Turkey, the 

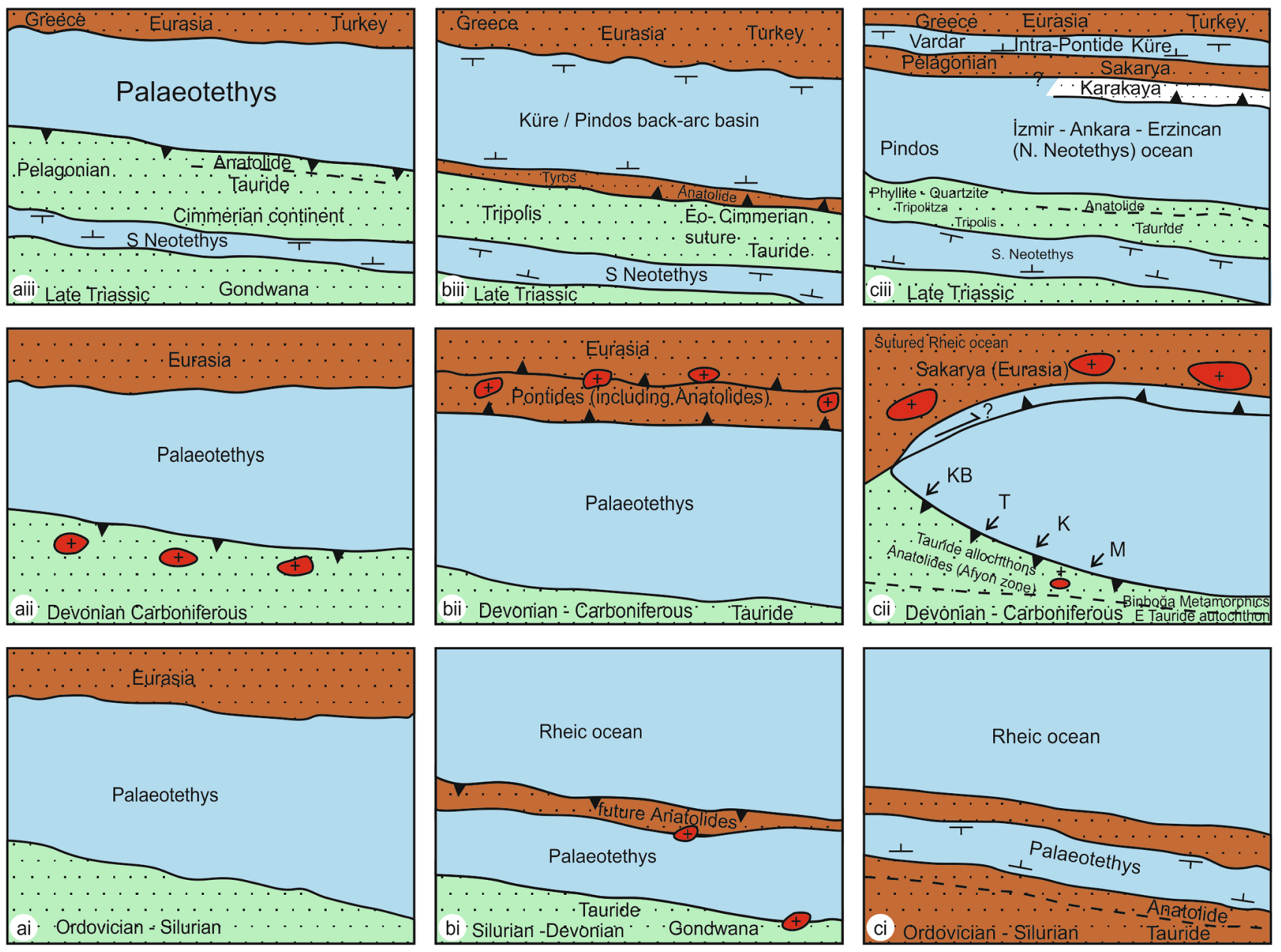

W

E W

E W

N SUBDUCTION MODEL

N SUBDUCTION MODEL WITH LOCALIZED S SUBDUCTION

Fig. 1 Alternative tectonic models of Palaeotethys, including the tectonic setting of the north margin of Gondwana during the Late Palaeozoic, the main subject of this paper. a Southward subduction model; b Northward subduction model; c double subduction model,

northern margin of Gondwana effectively formed a continental margin arc during the Late Palaeozoic. The arc was located along the borderland or off-margin separated by a marginal basin. Subduction of Palaeotethys terminated by collision of the rifted Cimmerian continent with Eurasia during the Early Jurassic. This was followed by opening of a Mesozoic ocean basin to the north (northern Neotethys). The above interpretations are based on the south-dipping tectonic models of Şengör and Y1lmaz (1981), Şengör et al. (1984), Göncüoğlu et al. (2000) and Romano et al. (2006).

Model 2 The Rheic ocean opened, probably during the Ordovician (Fig. 1bi). This ocean subducted southwards beneath Gondwana during Late Silurian-Devonian, detaching a continental strip ('ribbon continent') from Gondwana to create Palaeotethys (Fig. 1bi). The rifted Gondwana with mainly northward subduction of Palaeotethys, but also localised southward subduction during the late Carboniferous. See text for explanations and literature citations

fragment drifted northwards and accreted to Eurasia (future Anatolides) by Late Devonian. This was followed by construction of the continental margin arc (Sakarya arc) in the Pontides (Fig. 1bii). The Sakarya arc rifted during the Triassic to create a wide back-arc (marginal) oceanic basin in the north, close to Eurasia (Küre/Pindos back-arc basin). As this ocean widened, the frontal arc, fore-arc basin and accretionary prism migrated southwards towards Gondwana. Gondwana rifted during the Permian to create the Southern Neotethys, and as a result an elongate crustal sliver (Cimmerian continent) drifted northwards towards Eurasia (Fig. 1biii). The northward-moving Cimmerian continent collided with the southward-migrating Eurasian continental fore-arc fragment during the latest Triassic, finally closing Palaeotethys in Turkey. This interpretation is based on 
the tectonic models of Stampfli et al. (2001), Stampfli and Borel (2002), Eren et al. (2004), Stampfli and Kozur (2006), Stampfli et al. (2013), Moix et al. (2008, 2013). In a modification of the above back-arc basin interpretation, in Greece (S Aegean) collision of the southward-migrating Eurasian active margin fragment with the rifted 'Cimmerian' continent (Phyllite-Quartzite unit sensu stricto) is put at Middle Triassic (Ladinian) rather than latest Triassic (Zulauf et al. $2013,2015,2016,2018)$. In all variants of the above interpretation, the north margin of Gondwana remained passive throughout the Palaeozoic onwards.

Model 3 The Taurides and Anatolides remained along the northern margin of Gondwana during the Palaeozoic (Robertson and Dixon 1984, 2008; Robertson et al. 2004; Okay et al. 2006; Özbey et al. 2013). The Sakarya arc was constructed along the southern margin of Eurasia related to northward subduction of Palaeotethys (Ustaömer and Robertson 1993, 1997; Cocks and Torsvik 2006; Okay et al. 2006, 2008; Linnemann et al. 2007; P.A. Ustaömer et al. 2012; Ustaömer et al. 2013; Rolland et al. 2016; Topuz et al. 2019; Uğurcan et al. 2019). Late Carboniferous melanges and related units within the Anatolides (Konya Complex) and the Taurides (Lycian nappes), and also in the Karaburun Peninsula (E Aegean) are interpreted as fragments of a regional subduction complex that accreted to the northern margin of Gondwana (Robertson and Ustaömer 2009a). Late Carboniferous granitic rocks cutting the Afyon zone (Anatolides) represent continental margin arc magmatism (Candan et al. 2016; Ustaömer et al. 2020). The interpreted accretion and continental margin arc magmatism along both the Eurasian and Gondwana margins points to double subduction of Palaeotethys (Fig. 1cii). Limited subduction is inferred during the late Carboniferous (c. 320-300 Ma), either generally southwards (Robertson and Ustaömer 2009a, b, 2011; Ustaömer et al. 2019), or generally westwards (Okay and Topuz 2017). Palaeotethys closed throughout the south Aegean-Balkan region before the Permian (Robertson et al. 2004; Zanchi et al. 2003; Okay and Topuz 2017), coupled with right-lateral displacement near the Eurasian active margin (Fig. 1cii). The northern margin of Gondwana rifted to open the Neotethyan İzmir-Ankara-Erzincan ocean during the Triassic. With further northward subduction, the Karakaya Complex accreted, including seamounts (Fig. 1 ciii) (Pickett and Robertson 1996; P.A. Ustaömer et al. 2012; Ustaömer et al. 2016a). In model three, the northern margin of Gondwana was passive during the Palaeozoic, but switched to active during the Late Carboniferous; afterwards, the passive margin resumed until the collisional tectonics of the Late Cretaceous-early Cenozoic.

The geological development of the northern margin of Gondwana is obviously critical to help distinguish between the contrasting interpretations. Here, we consider some new and published information concerning Late Palaeozoic volcanogenic rocks within the Tauride and Anatolide crustal units of central and eastern Anatolia. We also summarise and re-evaluate the tectonic setting of the Late Carboniferous melanges and granitic rocks within the Anatolides (Afyon zone). Because these units are allochthonous we also need to restore the later Mesozoic-Cenozoic contractional tectonics that affects them in order to infer the Late Palaeozoic palaeogeography.

\section{Regional geology}

There are two main occurrences of Late Palaeozoic volcanogenic rocks within the Geyik Dağ (Tauride platform), one in the central Taurides and one in the eastern Taurides (Fig. 2).

First, there is a sparse record of Late Palaeozoic volcanism within the unmetamorphosed central Taurides, mainly in the form of localised tuffaceous and volcaniclastic sediments, and also rarely as lavas (Göncüoğlu et al. 2007). The volcanogenic rocks occur widely in the west-central Taurides, within the Sultan Dağ unit (Fig. 2), which is interpreted as part of the relatively autochthonous Geyik Dağ. Part of the succession in the Sultan Dağ (Kuz Member of the Harlak Formation) comprises grey- to violet-coloured slates, with occasional layers and lenses of fine-grained, chloritic, volcaniclastic sediments, interpreted as tuffs, together with basic lavas and grey- to green intraformational conglomerates (pebblestones) (Fig. $3 \log 1$ ). This volcanogenic succession is dated as early Carboniferous (Mississippian), specifically early Tournaisian-late Visean, based mainly on conodonts (Göncüoğlu et al. 2007). Secondly, there is a very small outcrop of basaltic extrusive rocks within the extension of the Geyik Dağ into the eastern Taurides, in the Feke area, of inferred Late Devonian or early Carboniferous age (Dalkılıç 2009; Çimen 2018) (Fig. 2).

Well-preserved tuffaceous sediments, for which we provide new sedimentological and geochemical evidence, occur within a thrust sheet making up the regional Aladağ unit in the easternmost central Taurides, known as the Çataloturan thrust sheet (Tekeli 1981; Tekeli et al. 1984; Balc1 2010; Alan et al. 2007) (Fig. 2). The succession is well dated as early Carboniferous, based mainly on conodonts and radiolarians (Göncüoğlu et al. 2007).

Late Palaeozoic meta-basic igneous rocks occur widely within the Binboğa metamorphic unit of the Eastern Taurides, which is generally correlated with the larger scale Malatya-Keban platform (MTA 2011) (Fig. 2). The metavolcanic rocks of the Binboğa unit stratigraphically underlie palaeontologically dated Permian platform carbonates (Perinçek and Kozlu 1984; Bedi et al. 2009, 2012; Bedi and Yusufoğlu 2018). Meta-igneous rocks are also present as isolated dykes farther east, where they transect the Keban metamorphic unit (part of the Malatya-Keban 


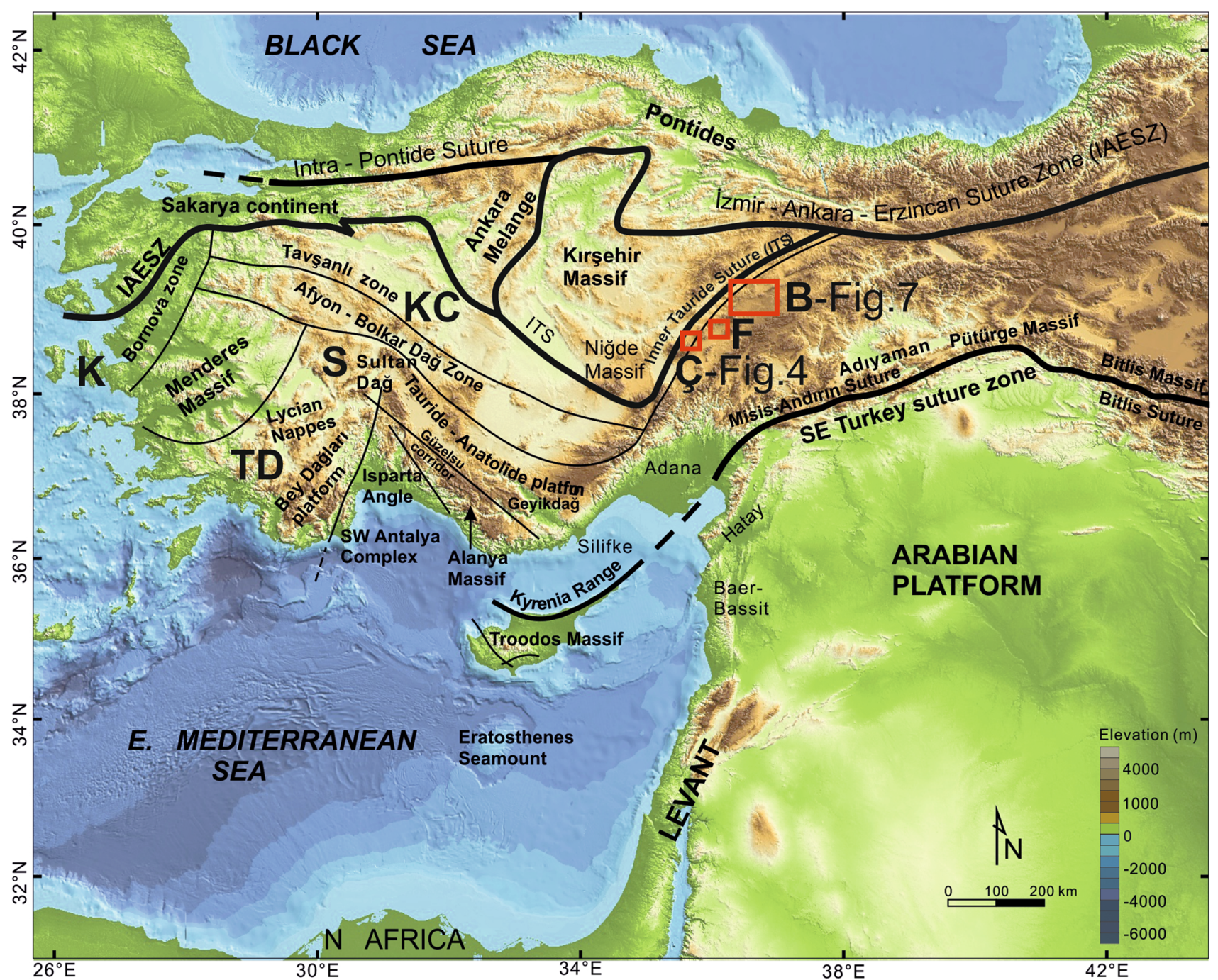

B Binboğa meta-lavas (Malatya Metamorphics)

Ç Çataloturan unit tuffs, Aladağ thrust sheet

F Tauride autochthon volcanics (Feke area)

K Karaburun melange, Karaburun Peninsula

KC Konya Complex (Afyon zone, Anatolides)

$S \quad$ Sultan Dağ volcanics \& tuffs (Tauride autochthon)

TD Teke Dere Unit (Lycian nappes)

Fig. 2 Outline tectonic map of Turkey showing the main tectonic zones, including the present study and comparative areas. Specific areas are marked by boxes and arrows. Main data source MTA (2011) (modified from Chen and Robertson 2020)

platform). The cross-cut metamorphic rocks are dated, palaeontologically, as Carboniferous. Dykes are absent from the overlying Permian and younger rocks suggesting a prePermian age for these dykes (Kaya 2016).
In this paper, we use the IGC International Chronostratigraphic Chart (Cohen et al. 2020). 
Fig. 3 Early Carboniferous tuffaceous sediments within the Taurus Mountains. a Sultan Dağ (relative autochthon; Geyik Dağ); b Nohutluk Formation of the Çataloturan thrust sheet (Aladă unit); simplified from Göncüoğlu et al. (2007). See Fig. 2 for locations

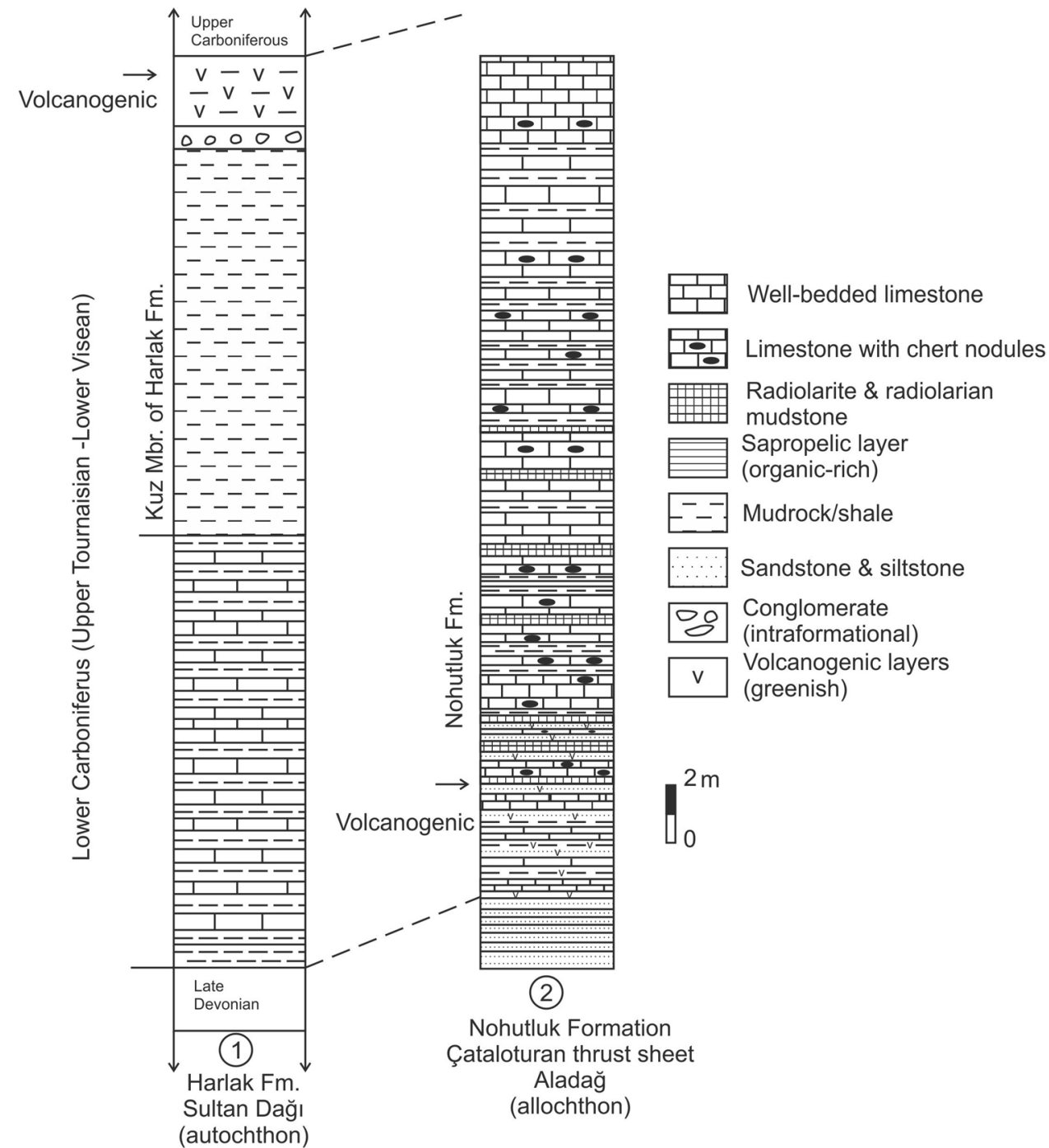

\section{Methods and materials}

For the tuffaceous sedimentary rocks of the Tauride Çataloturan thrust sheet, a section was logged; representative samples were studied petrographically, and six samples were chemically analysed for major and trace elements including rare earth elements (REEs). Petrographic study indicated the presence of abundant tuffaceous material, suggesting that useful information could be obtained geochemically for the associated volcanism.

Following petrographic study, four samples of aphyric or sparsely feldspar-phyric metabasalt from one section of the meta-volcanic rocks of the Binboğa metamorphic unit were found to be suitable for tectonic discriminant analysis, using a combination of major, trace and rare earth elements (REEs). However, petrographic study of the meta-basalts from another section showed that these are highly feldspar-porphyritic and so ill-suited to tectonic discrimination.

The analysis of major and trace elements and REEs (see Table 1) was carried out at Acme Analytical Laboratories Ltd., Vancouver, Canada. Major element contents were determined from a $\mathrm{LiBO}_{2}$ fusion by ICP-ES by using $5 \mathrm{~g}$ of sample pulp. Trace element and REE contents were determined from a $\mathrm{LiBO}_{2}$ fusion by ICP-MS by using $5 \mathrm{~g}$ of sample pulp. Detection limits range between 0.01 and 0.04 $\mathrm{wt} \%$ for major oxides, between 0.01 and $0.1 \mathrm{ppm}$ for trace and rare earth elements. The relative standard deviation for the REE is $\sim 5 \%$ and for all other trace elements is up to $10 \%$, with quality control using international geostandards. 


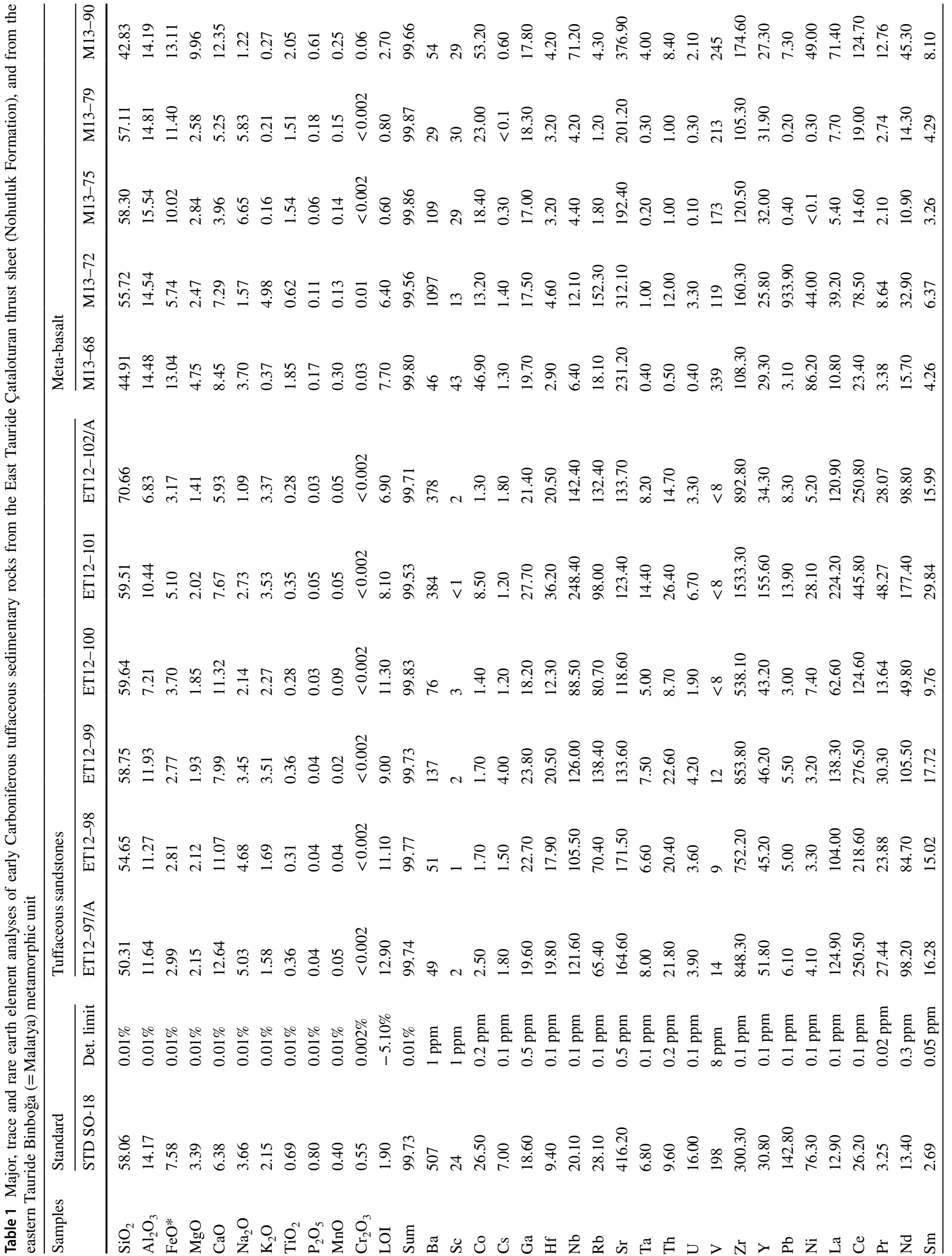




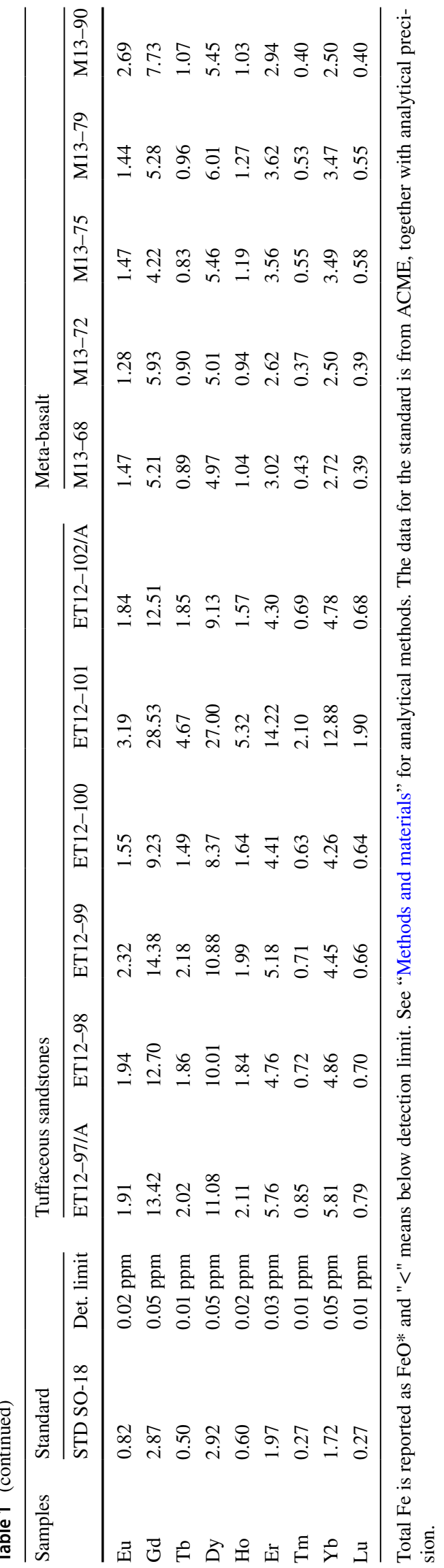

\section{Specific objectives}

Our specific objectives are as follows:

(1) To determine the setting of deposition and provenance of the early Carboniferous tuffaceous sediments of the Tauride Çataloturan thrust sheet;

(2) To discriminate the tectonic setting of the volcanogenic contribution to the Çataloturan succession;

(3) To determine the composition and magmatic affinity of the meta-volcanic rocks of the Late Palaeozoic Binboğa (Malatya) unit;

(4) To compare the compositions of the different Late Palaeozoic volcanogenic units, including a small occurrence within the eastern Tauride autochthon (Feke area);

(5) To review and re-evaluate information for the late Carboniferous melanges and granitic magmatism, particularly from the metamorphosed Afyon zone (Konya Complex) and from the unmetamorphosed Lycian nappes (Teke Dere unit) (Fig. 2).

(6) Finally, the assembled information and interpretations are used to help understand the geological development of the northern margin of Gondwana, and thereby help to test the alternative tectonic models of Palaeotethys during the Late Palaeozoic (Fig. 1).

\section{Early Carboniferous volcanogenic sediments of the Tauride allochthon}

\section{Stratigraphy and sedimentology of tuffaceous sediments}

The tuffaceous sediments are located within the Çataloturan thrust sheet, one of five main thrust sheets exposed in the Aladağ area (Fig. 2). These thrust sheets represent emplaced parts of the Mesozoic Tauride carbonate platform and its Late Palaeozoic substratum (Blumenthal 1952; Tekeli 1981; Tekeli et al. 1984; Alan et al. 2007; MTA 2011). The structurally lowest unit, the Yahyalı thrust sheet, includes evidence of high pressure-low temperature metamorphism (HP-LT) (Pourteau et al. 2010). The Carboniferous succession in the Çataloturan thrust sheet is dated as Mississippian (early Carboniferous) (Aksay 1980; Iş1k 1981). The succession studied, as exposed in the Nohutluk Tepe section (Figs. 3b, 4a, b), is specifically dated as late Tournaisian-late Visean using conodonts and radiolarians (Okuyucu and Vachard 2006; Göncüoğlu et al. 2007 and references).

The Nohutluk Tepe section begins with organic carbon-rich black shales and sandstones, of inferred 


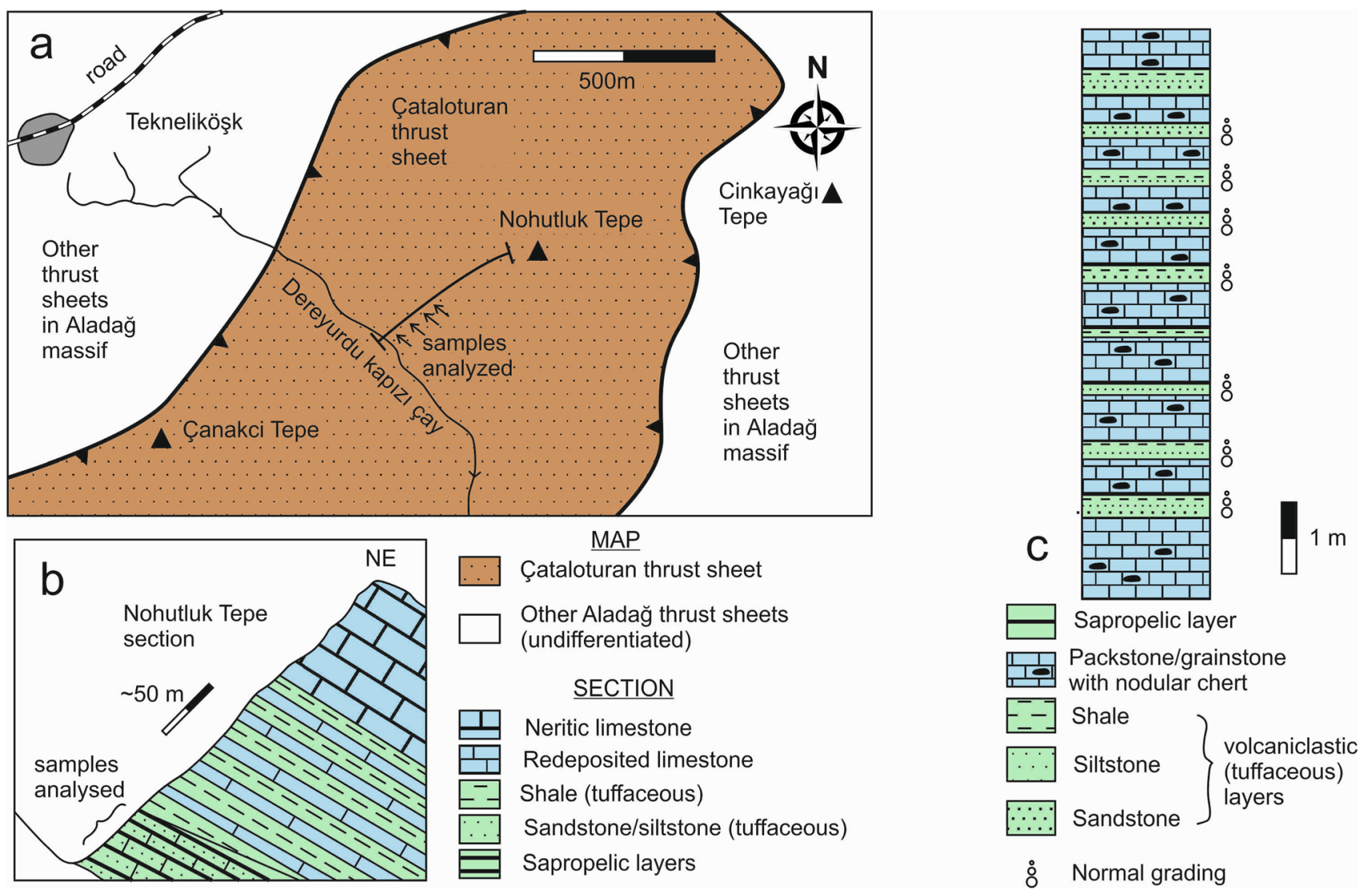

Fig. 4 Early Carboniferous Nohutluk Formation of the Çataloturan thrust sheet (Aladağ unit). a Outline geological map (modified from Göncüoğlu et al. 2007); b Local cross-section showing sample loca-

Devonian-Carboniferous age. The overlying succession is dominated by thin- to medium-bedded, grey- to brownishcoloured limestones (Fig. 5a, b) (Aksay 1980; Iş1k 1981; Okuyucu and Vachard 2006; Göncüoğlu et al. 2007). The limestones are fine- to medium-grained, with a packstonegrainstone texture (Fig. 5c). Individual limestone beds exhibit sharp bases, subtle normal grading, bioturbation and parallel lamination. Some beds are partially silicified or have lenticular to nodular black chert, of diagenetic replacement origin (Fig. 5d, upper part of photograph). Intercalations of greenish radiolarite occur throughout the lower to mid parts of the succession (Fig. 5e). The lower c. $25 \mathrm{~m}$ of the succession includes numerous intercalations of greenish, finely laminated volcanogenic mudstones and siltstones, together with rare fine- to locally mediumgrained volcaniclastic sandstones, mainly near the base of the succession (Fig. 5f). The finer-grained volcanogenic facies are commonly partly silicified. The tuffaceous material becomes finer-grained and decreases up-section, whereas redeposited neritic carbonate increases until the succession becomes shallow marine near the top. tions (this study); c Sedimentary log of part of the base of the section where green tuffaceous sediments are thickest, coarsest-grained and most abundant (this study). See Fig. 2 for location

\section{Petrography and geochemistry of tuffaceous sediments}

The thickest-bedded, relatively homogeneous volcaniclastic beds (individually up to $0.8 \mathrm{~m}$ thick) that occur near the base of the succession were sampled for petrographic and chemical analysis (Fig. 4c).

In thin section, the volcaniclastic sandstones are dominated by abundant angular plagioclase grains, altered volcanic glass (shards), together with monocrystalline quartz, set in a chloritized matrix (Fig. 5g). Grains of altered basalt and felsic volcanic rocks are visible in the coarsergrained facies. There is a patchy calcite spar cement. The volcaniclastic siltstones are composed mostly of feldspar, quartz and glass shards (altered), together with tiny muscovite laths, set in a greenish chloritic and calcareous matrix (Fig. 5h). Outlines of radiolarian tests are occasionally visible. The interbedded limestones, interpreted as calciturbidites, contain abundant echinoderm debris (e.g., spines), shell fragments, grains of basalt (with feldspar microphenocrysts) and common plagioclase. The 
petrography indicates that there was a strong- to dominant volcaniclastic input to these sediments.

The available geochemical data (Table 1) were plotted and interpreted using well-known compositional and discrimination diagrams that are designed for sedimentary or igneous rocks. Complete analyses (including REEs) of Carboniferous Tauride sandstones from other areas are not available. However, four analyses of Ordovician Tauride sandstones from the Antalya Complex (Antalya nappes) in the Alanya window, Southern Turkey (Robertson et al. 2020), were plotted for comparison. The Ordovician sandstones are chemically similar to Ordovician, Devonian, Carboniferous and Triassic shales from the Hadim (Aladağ) and Bolkar nappes of the Central Taurides (Mackintosh and Robertson 2012a). Detrital zircon geochronology, including evidence from late Carboniferous sandstones of the Yahyalı thrust sheet, Aladağ unit, indicates provenance from NE Gondwana (Ustaömer et al. 2020 and references). The Ordovician sandstones plotted are, therefore, indicative of the NE Gondwana provenance that does not include tuffaceous sediments.

On the $\log \left(\mathrm{SiO}_{2} / \mathrm{Al}_{2} \mathrm{O}_{3}\right)$ vs. $\log \left(\mathrm{Na}_{2} \mathrm{O} / \mathrm{K}_{2} \mathrm{O}\right)$ diagram (after Pettijohn et al. 1972), the Çataloturan unit tuffaceous samples plot as greywacke and litharenite (Fig. 6a), and as wacke, litharenite and arkose on the $\log \left(\mathrm{SiO}_{2} / \mathrm{Al}_{2} \mathrm{O}_{3}\right)$ vs. $\log \left(\mathrm{Fe}_{2} \mathrm{O}_{3} / \mathrm{K}_{2} \mathrm{O}\right)$ diagram (after Herron 1988) (Fig. 6b). On the Th/U vs. Th plot (after McLennan et al. 1993), the samples plot in the upper crust area, with indications of mild, but variable weathering (Fig. 6c). On the $\mathrm{Al}_{2} \mathrm{O}_{3}$ vs. $\mathrm{CaO}+\mathrm{Na}_{2} \mathrm{O}$ vs. $\mathrm{K}_{2} \mathrm{O}$ CIA (chemical index of alteration) diagram (after Nesbitt and Young 1984), the tuffaceous sediments plot in the vicinity of basalt (Fig. 6d). The lack of evidence of strong weathering is consistent with an origin as gravityreworked fallout tuff. On the average upper continental crust (UCC)-normalised plot, the samples are markedly enriched in $\mathrm{Nb}, \mathrm{Ta}, \mathrm{La}, \mathrm{Ce}, \mathrm{Nd}, \mathrm{Hf}, \mathrm{Zr}, \mathrm{Sm}, \mathrm{Tb}, \mathrm{Y}, \mathrm{Tm}$ and $\mathrm{Yb}$, but depleted in $\mathrm{Ba}, \mathrm{Sr}, \mathrm{K}, \mathrm{P}$ and Ti (Fig. 6e), consistent with their variable mixed volcanogenic, terrigenous and biogenic composition. On a shale-normalised REE plot, the samples have relatively flat patterns of REEs, similar to terrigenous shales, for example the North Atlantic shale composite (NASC) (Gromet et al. 1984), or the PAAS (post-Archean average Australian shale composite (Taylor and McLennan 1985). The marked negative Eu anomaly (Fig. 6f) reflects the abundance of plagioclase, as seen in thin sections (Fig. $5 \mathrm{~g}$, h). On the La vs. Th vs. Sc plot (after McLennan and Taylor 1984), the samples are strongly La-enriched, more so than upper continental crust (UCC) and typical of continental shale (PAAS) (Fig. 6g), which corresponds to the abundance of La-enriched volcanogenic material. On the $\mathrm{Th} / \mathrm{Sc}$ vs. $\mathrm{Zr} / \mathrm{Sc}$ plot (after McLennan et al. 1993), the samples are strongly enriched in $\mathrm{Zr}$ and $\mathrm{Th}$, compared to basalt, andesite, or UCC (Fig. 6h). The relative enrichment in Th and Zr represents the high volcanogenic content.
The petrographic evidence, coupled with the relatively high, e.g., $\mathrm{Zr}$ and $\mathrm{Th}$, indicates that the Çataloturan unit sediments are rich in volcanogenic material and are, therefore, suitable for plotting on several igneous rock discrimination diagrams. On the $\mathrm{Zr} / \mathrm{Ti}$ vs. $\mathrm{Nb} / \mathrm{Y}$ diagram (after Pearce 1996) the samples plot mainly in the trachyte to alkali rhyolite field (Fig. 6i). On the Nb vs. Y plot (after Pearce et al. 1984), compared to different granites, the samples plot in the within-plate granite field (Fig. 6j). On the chrondrite-normalised REE plot, the samples show a marked enrichment in light rare earth (LRE) elements versus heavy rare earth (HRE) elements. The strong negative Eu anomaly (Fig. 6k) confirms the abundance of plagioclase in the source magma (Rollinson 1993). Last, on the Th/Y vs. Ta/Yb diagram (after Pearce 1982), the samples mainly plot in the within-plate volcanic zones, overlapping with MORB and WPB areas (Fig. 61).

On all of the above plots the Ordovician sandstones from the Tauride Antalya unit are consistent with the composition of terrigenous shale (e.g., Fig. 6e-h), andesite and basaltic andesite (Fig. 6i), volcanic arc granite + syn-collisional granite (Fig. 6j) and active continental margins (Fig. 61). The sandstones are variably altered (Fig. 6a, c, d). The source of the sandstones was the Neoproterozoic-Cambrian basement of NE Gondwana, quite different from that of the Carboniferous tuffaceous sediments of the Çataloturan unit. This supports the use of igneous tectonic discrimination diagrams to interpret the origin of the tuffaceous sediments.

\section{Interpretation of the tuffaceous sediments}

The tuffaceous sediments accumulated in relatively deep water $(100 \mathrm{~s} \mathrm{~m})$ in a lower slope or proximal base-ofslope setting during the early Carboniferous (late Tournaisian-early Visean) (Göncüoğlu et al. 2007). The petrography indicates that the sediments have a high volcanogenic content, as indicated by the abundance of altered glass (tephra), plagioclase and volcanic rock fragments. However, there is a subordinate contribution of siliciclastic (terrigenous) material, as represented by polycrystalline (metamorphic) quartz and mica, together with minor amounts of biogenic material, mostly radiolarians. The normal-graded tuffs were ejected from a volcanic centre some distance away, settled to the seafloor and were then redeposited by turbidity currents. Fine-grained tuffaceous laminae are likely to be the product of direct ash fallout. Volcanism possibly began with an explosive pulse and then waned, judging from the upward general decrease in the relative abundance and grain size of the tuffaceous sediments. The interbedded calciturbidites are dominated by shallow-water-derived carbonate detritus and represent different depositional events. However, they include detrital volcanic grains. This suggests that the tuffaceous sediments relate to volcanism within, or adjacent to, 

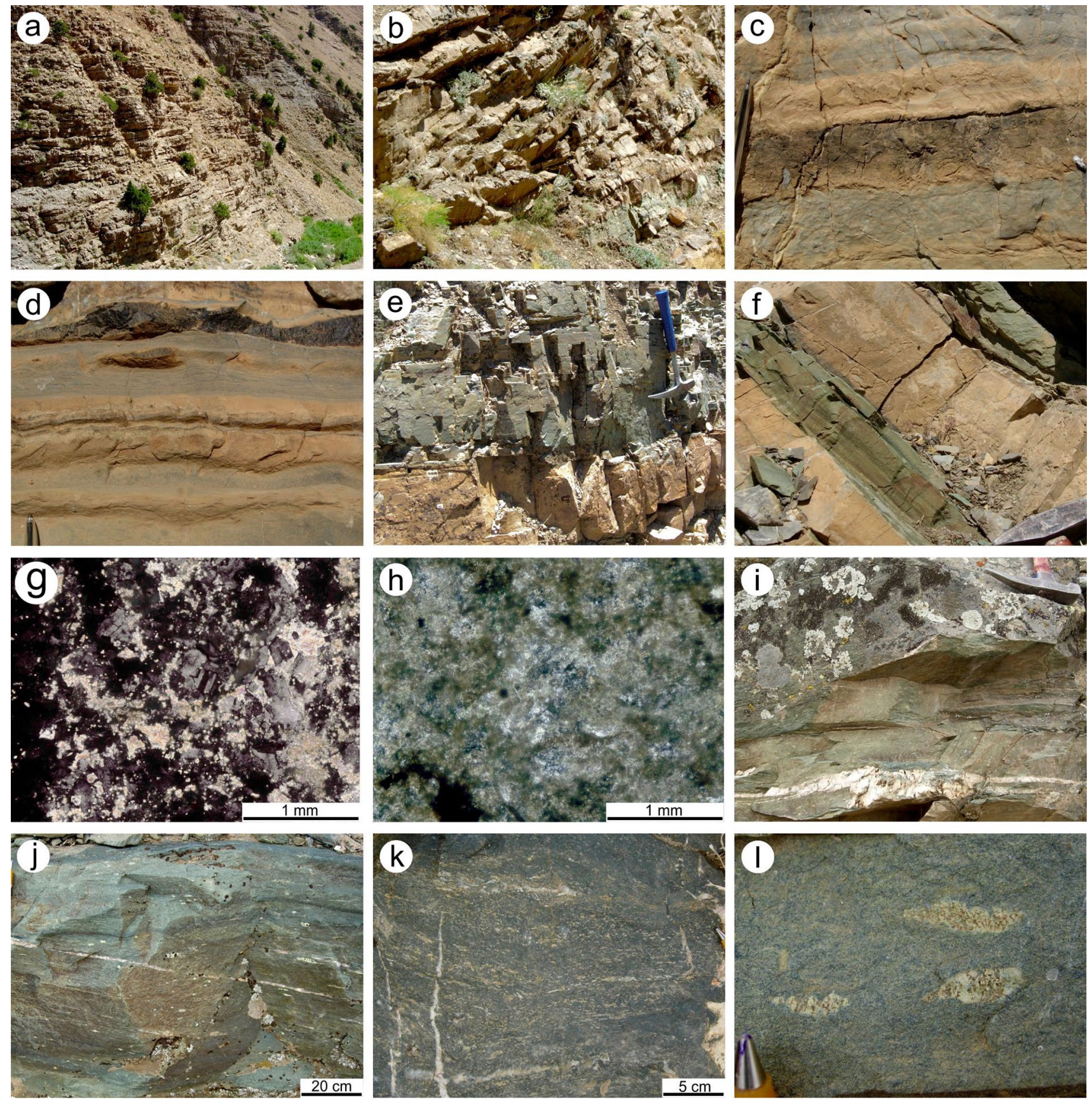

the deep-water basin rather than being wind-carried from far away.

The chemical data confirm that the tuffaceous sandstones are relatively mafic, similar to greywackes and some litharenites (Fig. 6a, b). The compositions are enriched in REEs compared to average terrigenous shales (NASC or PAAS). The strong relative enrichment in LILEs on the chrondrite-normalised plot (Fig. 6k) is similar to that of within-plate volcanics (Fig. 61). The relative enrichment in $\mathrm{Zr}$ (Fig. 6h) is also consistent with 'enriched' alkaline volcanism.

In summary, the early Carboniferous tuffaceous sediments are interpreted as the product of evolved alkaline volcanism, variably mixed with continentally derived silt and siliceous biogenic material. 
४Fig. 5 Field photographs and photomicrographs of the early Carboniferous tuffaceous sediments from the Nohutluk section, Çataloturan thrust sheet $(\mathbf{a}-\mathbf{h})$, and of the Late Palaeozoic meta-basaltic volcanics of the Binboğa (=Malatya) metamorphic unit in the E. Taurides (i-l). a Lower part of the early Carboniferous Nohutluk Formation. The section is dominated by very well-bedded, redeposited limestones (packstone/grainstone), with greenish volcaniclastic layers, mainly near the base (thickness of strata shown $=$ c. $35 \mathrm{~m}$ ) (view to SE); $\mathbf{b}$ Lower part of the section, as a; note the greenish volcaniclastic layer near the base (c. $80 \mathrm{~cm}$ thick); c Well-bedded, fine to mediumgrained packstone/grainstone; beds are sharp-based, weakly normalgraded, parallel laminated and variably bioturbated; part of the outcrop in $\mathbf{b}$; pen for scale; $\mathbf{d}$ Normal-graded thin beds of packstone/ grainstone, intercalated with micritic limestone, with dark organic carbon-rich laminae and nodules of black chert of diagenetic replacement origin; part of the section in $\mathbf{b}$; pen for scale; e Intercalation of green tuffaceous siltstone (partially silicified). The intercalation comprises at least three depositional events. The pale brown interbed represents redeposited packstone/grainstone; part of the section in $\mathbf{b}$; hammer for scale; $\mathbf{f}$ thin bed of largely silicified, greenish grey finegrained tuffaceous siltstone, interbedded with redeposited packstone/ grainstone; part of the section in $\mathbf{b}$; hammer head for scale; g Photomicrograph of relatively coarse-grained, redeposited volcaniclastic sandstone; contains abundant angular grains of plagioclase, together with volcanic glass (isotropic) and partial diagenetic replacement by calcite spar; part of section in $\mathbf{b}$; $\mathbf{h}$ typical greenish, fine-grained tuffaceous siltstone with small angular feldspar crystals and volcanic glass shards (isotropic); also poorly preserved radiolarians in a chloritic matrix, partly replaced by calcite; part of section in $\mathbf{b} ; \mathbf{i}$ Greenish foliated amphibolite of the Binboğa metamorphic unit, with folded metasomatic quartz vein (near base); $15 \mathrm{~km}$ WSW of Afşin, E Taurides; hammer for scale; $\mathbf{j}$ Amphibolite (partly replaced by chlorite), with deformed feldspar porphyroblasts (same section as i); k Foliated amphibolite, with deformed metasomatic grains and segregations (same section as i); I Dark-coloured foliated amphibolite, with feldspar-rich layers; cut by quartz veins at right angles (same section as $\mathbf{l}$ ); pen nib for scale

\section{Late Palaeozoic meta-basic igneous rocks of the Binboğa metamorphic unit}

Meta-basaltic extrusive rocks and minor meta-intrusive rocks are mapped within the overall Late Palaeozoic succession in eastern Anatolia (Figs. 2, 7). Regionally, the metamorphic rocks have three main outcrops, separated by major neotectonic left-lateral faults (MTA 2011). The outcrop to the northwest, the main area of interest here, is mapped as the Binboğa Metamorphics (Perinçek and Kozlu 1984; Özgül and Kozlu 2002). The largest metamorphic outcrop, which is located south and southwest of Malatya, is termed the Malatya Metamorphics. The outcrop to the east and southeast of Malatya is known as the Keban Metamorphics. Prior to neotectonic left-lateral fault displacement, these three outcrops formed parts of a regional-scale metamorphic unit (Malatya-Keban platform) (MTA 2011). The overall succession has some similarities with the Afyon zone (Anatolides) to the west, for example the presence of up-to low high-pressure metamorphism (Bedi et al. 2009; Bedi and Yusufoğlu 2018; Robertson et al. 2021a). However, there are some significant differences with the Afyon zone, notably the presence of Late Cretaceous granitic rocks, only in the Malatya-Keban platform including the Binboğa metamorphics (Parlak 2006; Rızaoğlu et al. 2009; Karaoğlan et al. 2016).

The Binboğa metamorphic outcrop includes widespread intercalations of meta-basic igneous rocks, mainly amphibolite, within a mixed carbonate-siliciclastic shelf succession (Yoncayolu Formation) (Perinçek and Kozlu 1984; Bedi et al. 2009). The exposures studied here are located in the relatively remote Binboğa Mountains that remain to be mapped in detail. Interbedded meta-carbonates have so far yielded only Eotuberitina sp. and Tetraxis sp. (benthic foraminifera), suggestive of a Late Devonian-Carboniferous age. The overlying recrystallised limestone succession (Çayderesi Formation) includes a rich assemblage of large foraminifera, indicating a Late Permian age (Perinçek and Kozlu 1984; Bedi et al. 2009). A Carboniferous age of the volcanism is likely, similar to the inferred age of the dykes in the Keban metamorphics further east (see above). However, a Devonian age cannot be excluded in view of the rare occurrences of Late Devonian or early Carboniferous volcanics within the relatively autochthonous succession in the Eastern Taurides (Feke area) (Dalkılıç 2009; Çimen 2018) (see below).

\section{Stratigraphy of the meta-volcanics}

Two sections of the Binboğa metamorphic unit were studied. The first section (Fig. 7, $\log 1$ ) exposes basaltic lava flows, individually up to tens of metres thick (Fig. 5i-1). The meta-lavas are strongly foliated, sheared and folded and are interbedded with meta-quartz sandstones/siltstones and recrystallised limestones (marble). There are also occasional intraformational conglomerates and also slumped beds that together indicate reworking and soft-sediment instability. Measurements of fold axial planes and fold hinges indicate deformation about c. E-W axes (Robertson et al. 2021b). The second section (Fig. 7, $\log 2$ ), located c. $10 \mathrm{~km}$ to the northwest, is similar although the meta-lavas there are highly feldspar-phyric and so unsuited to chemical analysis.

\section{Petrography and geochemistry of the meta-volcanics}

In thin section, the meta-lava exhibits granoblastic to nematoblastic textures, with preferred orientation of hornblende (65-85\%) and plagioclase (15-20\%). Dark hornblendedominated layers (Fig. 8a, b) typically alternate with lighter bands, lenses and stringers of plagioclase, epidote and minor quartz (Fig. 8c, d). Plagioclase is extensively altered to calcite, albite and sericite. The mineralogy of the samples studied suggests greenschist to lower amphibolite facies conditions. However, low high-pressure metamorphism, in 

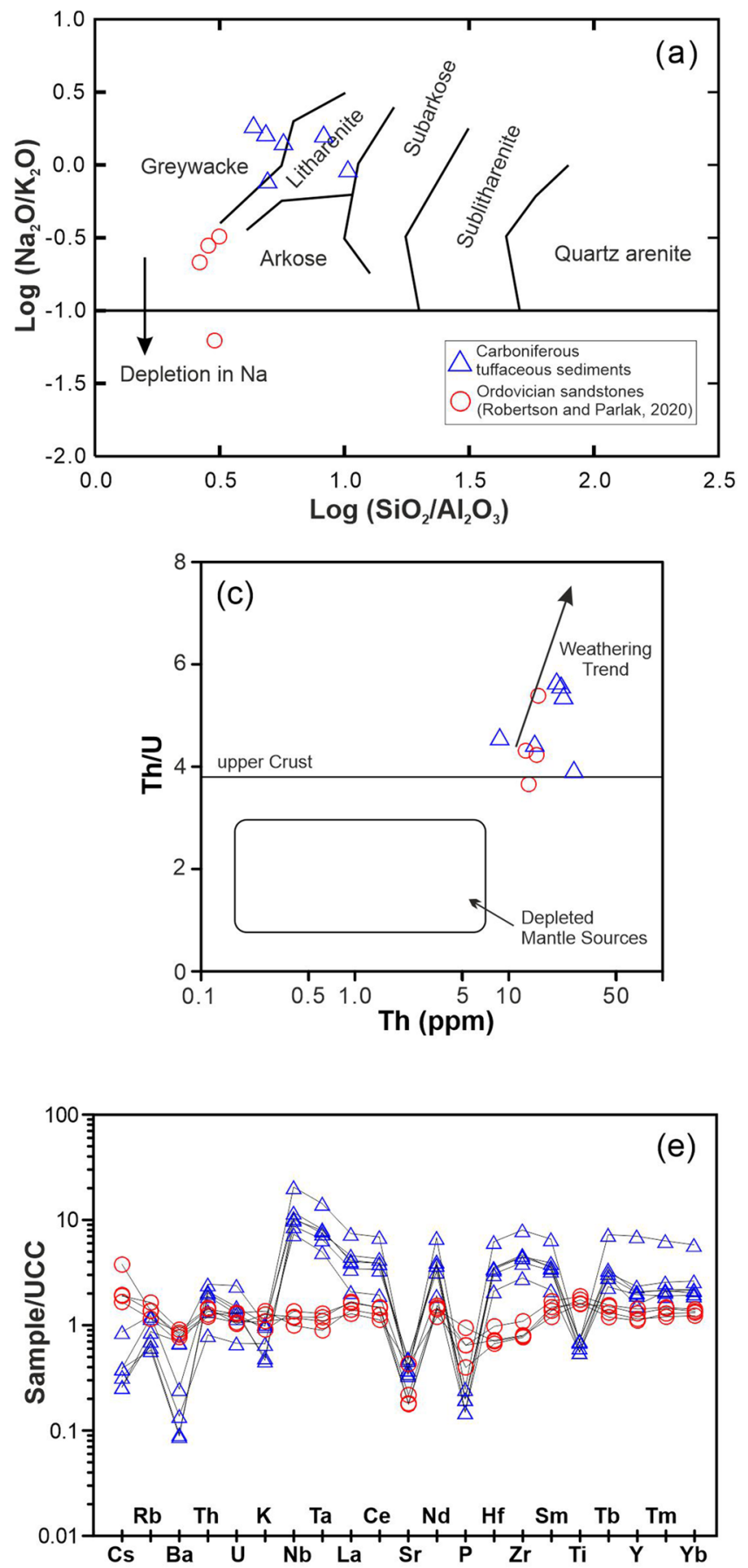

Fig. 6 Chemical analyses of the early Carboniferous tuffaceous sedimentary rocks of the Nohutluk Formation, Çataloturan thrust sheet (Tauride allochthon), plotted on well-known sedimentary and igneous rock discrimination diagrams. Published Ordovician terrigenous sandstones from the Taurides (Antalya Complex) are plotted for comparison (from Robertson et al. 2020). a $\log \mathrm{Na}_{2} \mathrm{O} / \mathrm{K}_{2} \mathrm{O}$ vs. $\mathrm{Log} \mathrm{SiO}_{2} /$ $\mathrm{Al}_{2} \mathrm{O}_{3}$ discrimination diagram (after Pettijohn et al. 1972); b Log $\mathrm{Fe}_{2} \mathrm{O}_{3} / \mathrm{K}_{2} \mathrm{O}$ vs. $\mathrm{Log} \mathrm{SiO}_{2} / \mathrm{Al}_{2} \mathrm{O}_{3}$ discrimination diagram (after Herron 1988); c Th/U vs. Th plot (after McLennan et al. 1993); d $\mathrm{Al}_{2} \mathrm{O}_{3}$ vs. $\mathrm{CaO}+\mathrm{Na}_{2} \mathrm{O}$ vs. $\mathrm{K}_{2} \mathrm{O}$ CIA chemical index of alteration diagram (after Nesbitt and Young 1984); e Element concentrations normalised to average upper continental crust (UCC); normalising values are from Rudnick and Gao (2003) and $\mathrm{Hu}$ and Gao (2008); f REE elements normalized to North Atlantic shale composite (NASC); nor-
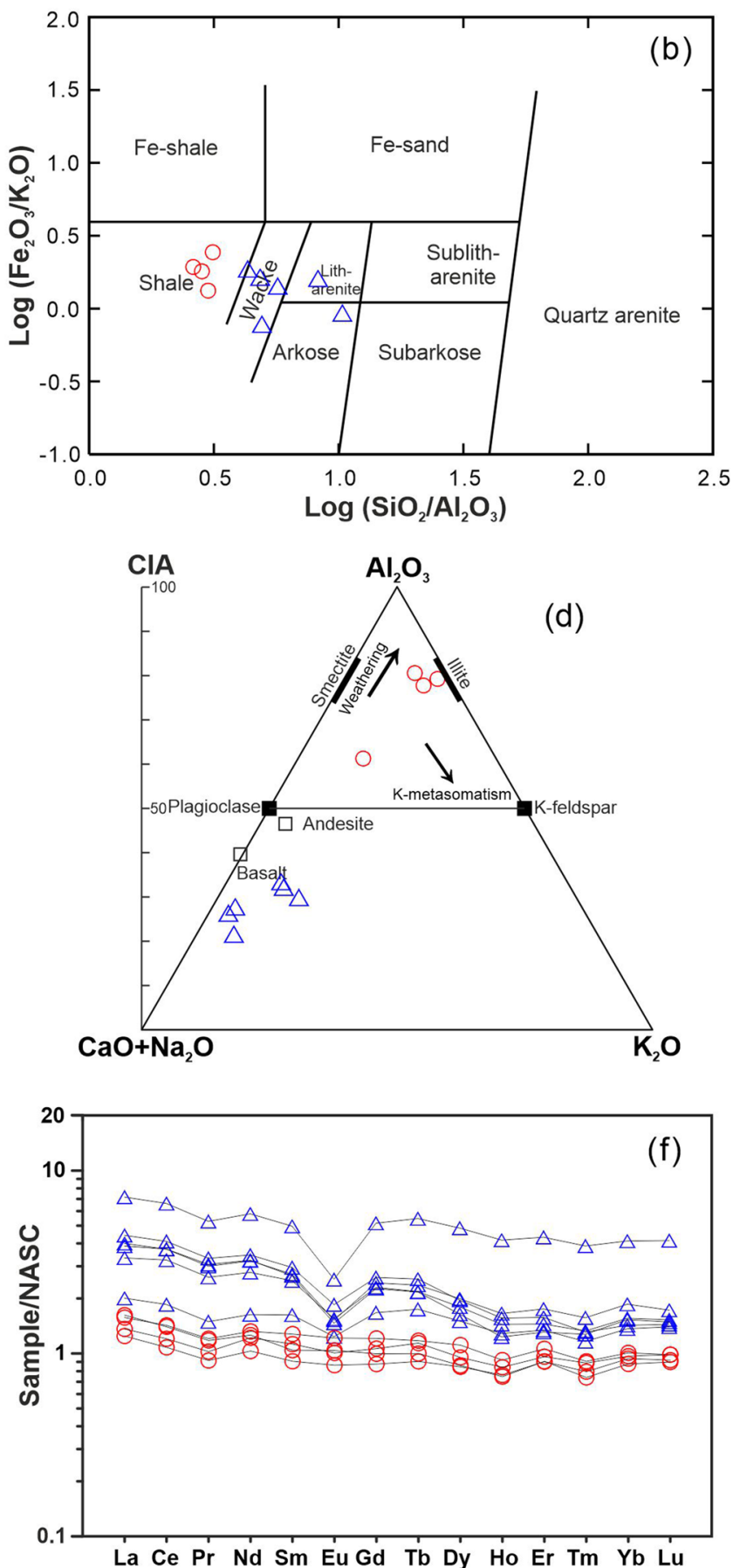

malising values from Gromet et al. (1984); g La vs. Th vs. Sc plot; the values of potential source rocks (grey squares) are from McLennan and Taylor (1984); h Th/Sc vs. Zr/Sc plot (after McLennan et al. 1993). Black solid circles indicate the average compositions of granite, andesite and basalt (after Condie 1993). Grey square represents the average compositions of UCC (Rudnick and Gao 2003; Hu and Gao 2008). The purple arrow indicates the trend from basic to felsic rock, and the green arrow the sedimentary recycling trend (i.e., zircon addition); i Zr/Ti vs. $\mathrm{Nb} / \mathrm{Y}$ volcanic rock classification diagram (after Pearce 1996); j Nb vs. Y plot for discrimination of granitic rocks (after Pearce et al. 1984); $\mathbf{k}$ REE concentrations, normalised to chondrite; normalising values from Sun and McDonough (1989); $1 \mathrm{Th} / \mathrm{Yb}$ vs. Ta/Yb diagram (after Pearce 1982). See text for explanation 

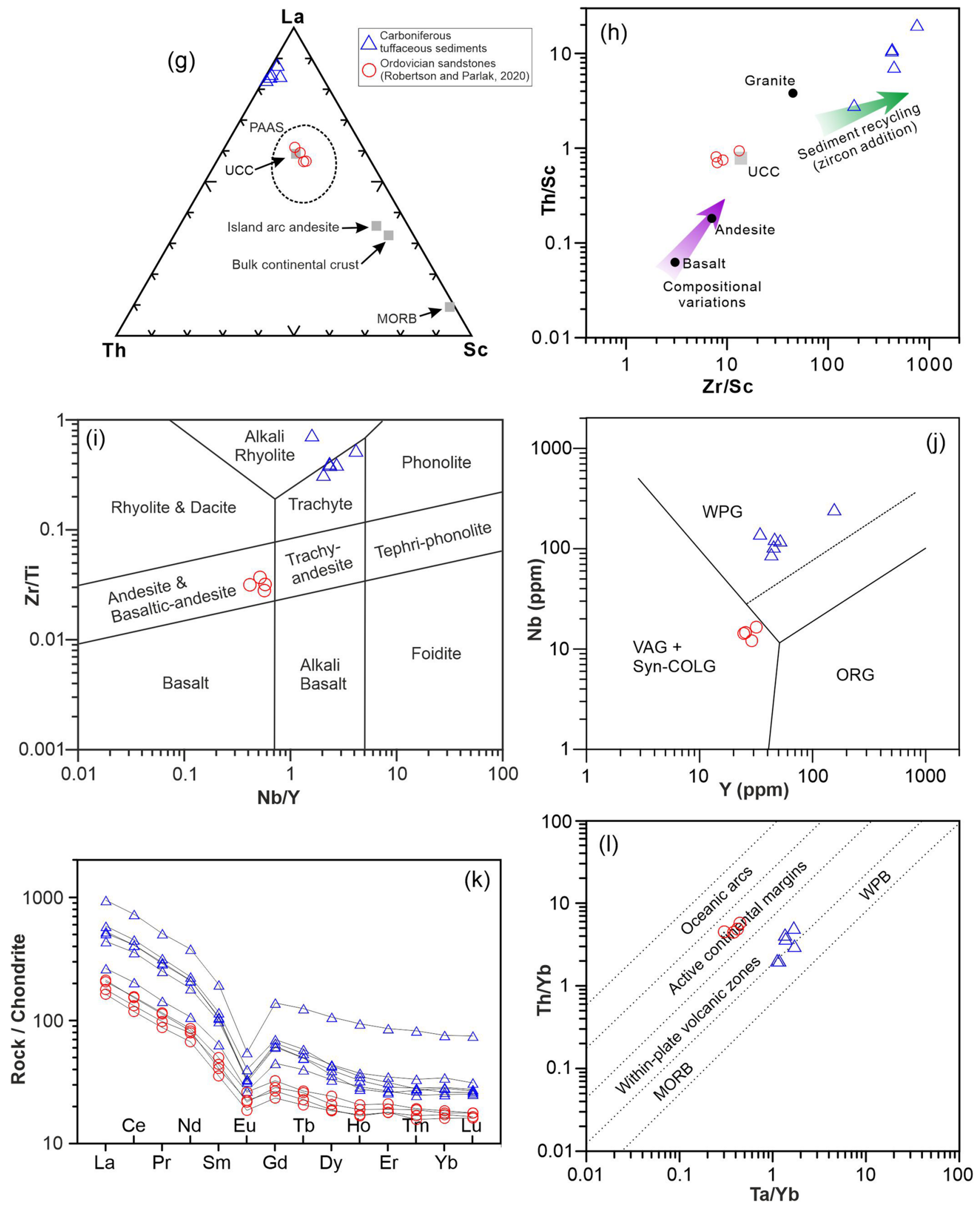

Fig. 6 (continued) 

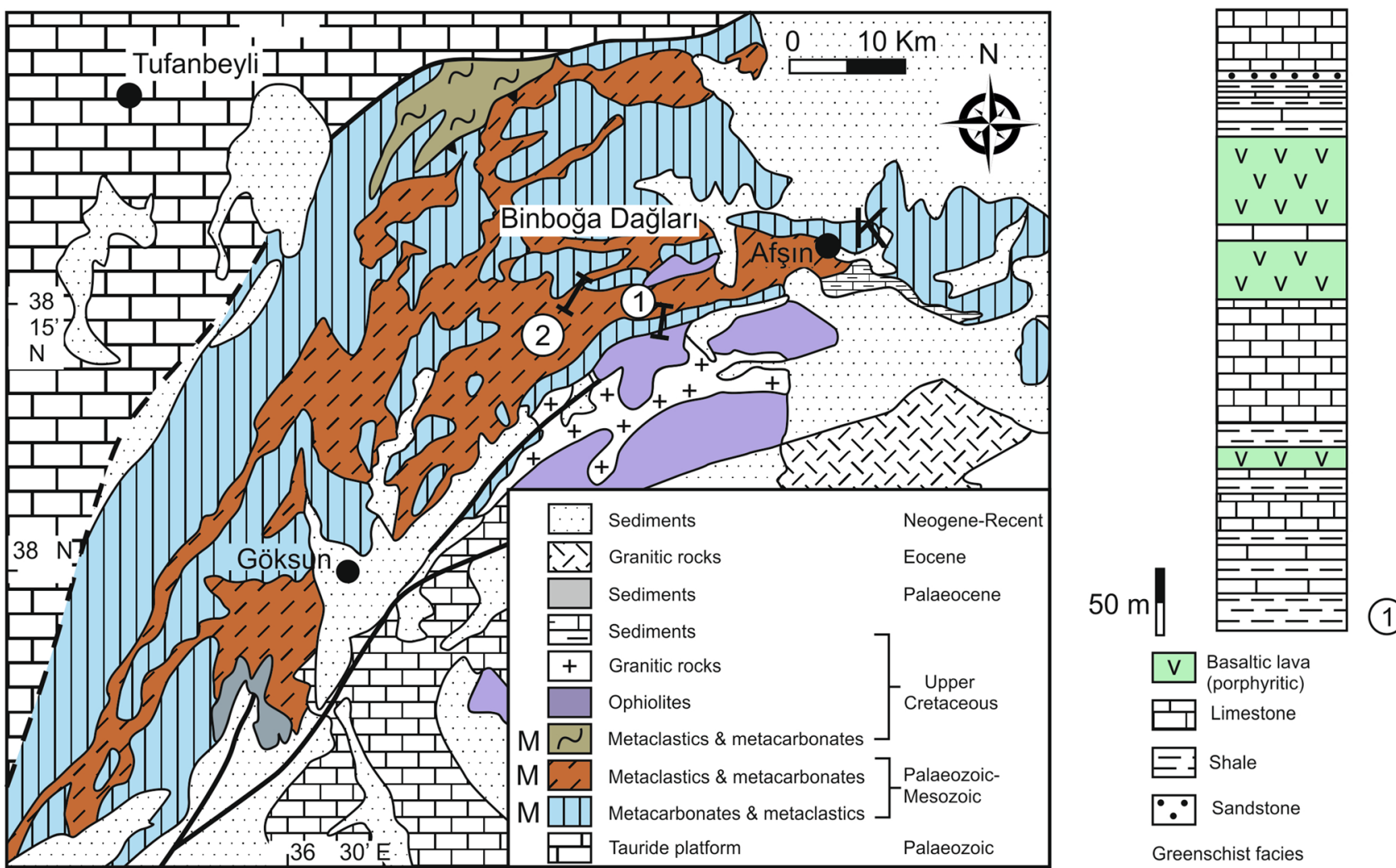

Fig. 7 Outline geological map of part of the East Taurides showing the locations of the two sections of Late Palaeozoic meta-basaltic volcanics studied within the Binboğa (=Malatya) metamorphic unit, together with a log of one succession (no. 1) that provided rocks suit-

places, is suggested by reports of glaucophane within the Malatya Metamorphics (Bedi et al. 2009). Low-grade metamorphism, recorded by Bozkaya et al. (2007), may represent retrograde metamorphism.

Four samples of relatively non-porphyritic meta-lava (M13.72, 75, 79, 90) were chemically analysed (see "Methods and materials"). Three of these samples (M13.72, 75, 79) were collected throughout a c. 80 m-thick interval of amphibolite, interbedded with marble. Sample M13.90 was collected from a c. $1.5 \mathrm{~m}$-thick interval of amphibolite, c. $300 \mathrm{~m}$ higher in the succession, representing one of the uppermost volcanogenic layers.

In addition, a rare clast of meta-basalt (M13.68) was analysed from Late Cretaceous meta-debris flow-deposits in the uppermost part of the stratigraphy within the Binboğa metamorphics. This unit is known as the Karaböğ̈̈rtlen Formation, with its type area in the western Taurides (Muğla region) (MTA 2011). The Karaböğürtlen Formation is inferred to be of Late Cretaceous age, mainly based on occurrences of rudist bivalves (Bedi et al. 2009; Robertson et al. 2021a). The Karabögürtlen Formation commonly includes thin- to medium-bedded greenish to brownish, foliated, porphyritic metabasic igneous rocks between schists able for chemical analysis. Map simplified from MTA (2011). Letter: K Sample locality of basaltic clast within the Late Cretaceous Karaböğürtlen Formation

and calcschists. Most of these are lava flows but some could represent dykes and/or sills (Bedi et al. 2009).

We observed scattered meta-basaltic clasts (up to $10 \mathrm{~s} \mathrm{~cm}$ in size) within meta-matrix-supported conglomerates during our study, near Afşin, but no in situ lava flows in this area (Fig. 7). The analysed meta-lava clast came from a depositional unit of matrix-supported conglomerate, c. $2.5 \mathrm{~km} \mathrm{NE}$ of Afşin (near Abaz Tepe, GPS: 37S 0329013/4236061). This meta-conglomerate is dominated by sub-rounded boulders of marble (up to several $\mathrm{m}$ in size), with subordinate meta-lava clasts. Associated units of matrix-supported conglomerate are up to $10 \mathrm{~m}$ thick, individually. The Karaböğürtlen Formation includes large-scale debris-flow deposits ('olistostromes') including the unit sampled. The formation is interpreted as part of a regional-scale flexurally-controlled foredeep, related to Late Cretaceous ophiolite emplacement (Robertson et al. 2013, 2021a). The analysed meta-basalt clast was probably derived by reworking of basaltic flows within the Late Cretaceous succession. However, derivation from deeper-level Late Palaeozoic volcanic rocks cannot be excluded.

LOI (loss on ignition) values in the analysed samples range from 0.8 to 7.7 wt.\%, consistent with moderate 

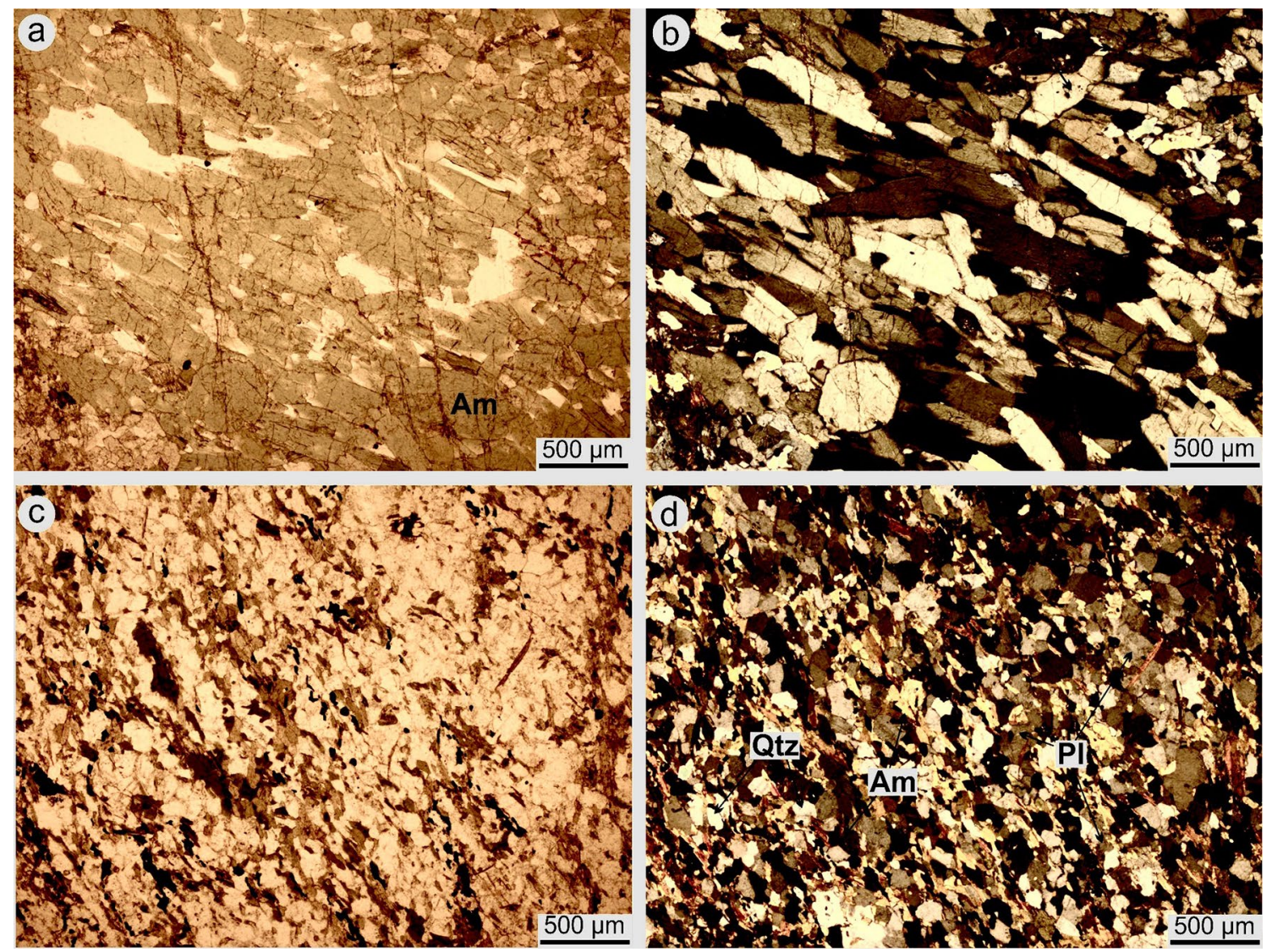

Fig. 8 Photomicrographs of Late Palaeozoic meta-igneous rocks from the Binboğa (=Malatya) metamorphic unit (west of Afşin). a, b Amphibolite displaying a nematoblastic texture, viewed under plane-plane and cross-polarised light, respectively; c, d Quartz-plagi-

oclase-amphibole schist viewed under plane-plane polarised light and crossed polarised light, respectively. Letters: Am-amphibole; Qtzquartz; Pl-plagioclase. See text for explanation

alteration (Lechler and Desilets 1987). Immobile elements including $\mathrm{Ti}, \mathrm{Nb}, \mathrm{Ta}, \mathrm{Zr}$, Y and REES were used to identify rock groups, petrogenetic trends and tectonic environments (Pearce and Cann 1973; Floyd and Winchester 1975, 1978; Pearce and Norry 1979). On the Nb/Y vs. Zr/Ti protolith discrimination diagram (after Pearce 1996), the meta-lavas plot as basalt, andesite and basaltic andesite and alkali basalt, whereas the clast from the Karabögüurtlen Formation is basaltic (Fig. 9a). On the Y/Ta vs. Y/Nb plot, indicative of magmatic affinity, the samples range from near N-MORB (normal mid-ocean ridge basalt), to near E-MORB (enriched mid-ocean ridge basalt) and near OIB (ocean island basalt) (Fig. 9b). Chondrite-normalised spider diagrams (Fig. 9c) indicate two trends: E-MORB and OIB. Two samples (ME.13-72 and 90) show significant LREE (light rare element) enrichment with respect to HREEs (heavy rare elements) $\left(\mathrm{La}_{\mathrm{N}} / \mathrm{Yb}_{\mathrm{N}}=11-20\right)$, similar to WPB (within-plate basalt) and OIB. The other two lava samples (M13.75 and 79) have less-enriched patterns $\left(\mathrm{La}_{\mathrm{N}} / \mathrm{Yb}_{\mathrm{N}}=1.1-1.6\right)$. The clast has a moderately enriched pattern $\left(\mathrm{La}_{\mathrm{N}} / \mathrm{Yb}_{\mathrm{N}}=2.8\right)$. On the N-MORB-normalised multi-element plots, the rocks show moderately 'enriched', to strongly 'enriched' patterns. The sample from the highest stratigraphical level of the succession sampled (M13-90) is a highly enriched alkaline basalt. Four samples have negative $\mathrm{Nb}$ and $\mathrm{Ta}$ anomalies, indicative of a chemical subduction influence (Fig. 9d) (see below). On the $\mathrm{Ta} / \mathrm{Yb}$ vs. $\mathrm{Th} / \mathrm{Yb}$ diagram (after Pearce 1982) (Fig. 9e), one sample plots near E-MORB and one near OIB, whereas the other three samples plot in the volcanic arc field. On the $\mathrm{Zr} / \mathrm{Y}$ vs. Nb/Y diagram (after Fitton 2007), the samples mainly plot outside the $\mathrm{Zr} / \mathrm{Y}$ vs. $\mathrm{Nb} / \mathrm{Y}$ depleted mantle-enriched mantle source array (Fig. 9f), mainly owing to relative $\mathrm{Nb}$ depletion.

\section{Interpretation of the meta-volcanic rocks}

The meta-lavas have the chemical characteristics of withinplate, i.e., rift or seamount extrusives. They are interbedded with shallow-water continental shelf-type siliciclastic and carbonate sediments, consistent with an extensional setting. However, there is no evidence of deep-water conditions (e.g. chert), in contrast to the unmetamorphosed tuffaceous 

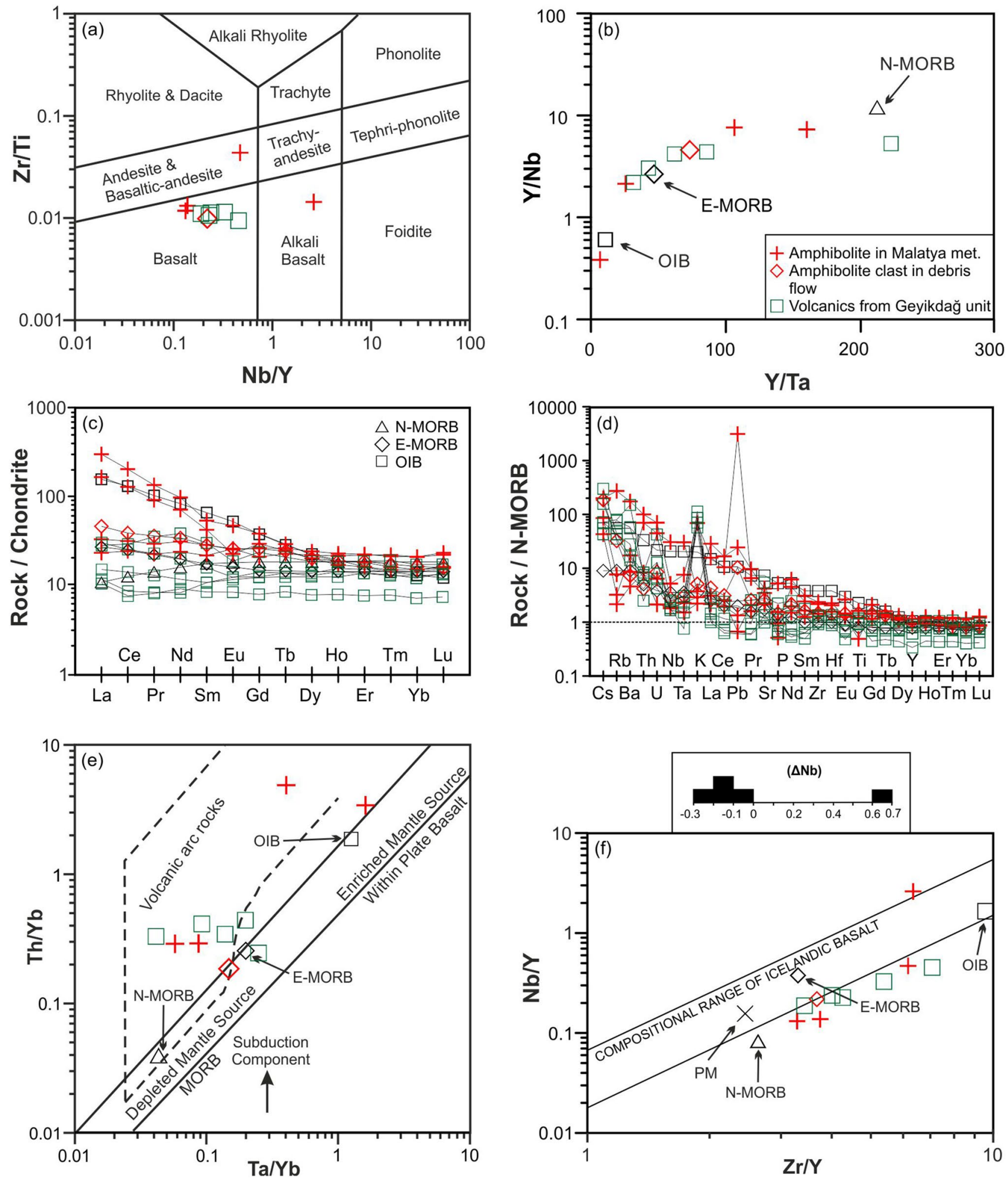

sediments of the Çataloturan thrust sheet (Aladağ unit). This suggests that platform deposition kept pace with any extension-related subsidence. The most 'enriched' sample, close to OIB in composition, is typical of a low-degree partial melt of a spinel peridotite mantle, in a continental rift setting

(e.g., Fitton 2007). The near-E-MORB sample represents a greater degree of partial melting, potentially of compositionally similar upper mantle. In a rift setting, co-existing OIB and E-MORB can be explained by a mantle plume or by enriched "blobs" or "streaks" in the upper mantle (Fitton 
4Fig. 9 Geochemistry of meta-igneous rocks from the Binboğa (=Malatya) metamorphic unit (SW of Afşin; see Fig. 7). Four of the samples are from the intact Late Palaeozoic succession (Binboğa metamorphic unit), whereas one is a clast from within syn-tectonic mass-flow units ('olistostromes') near the top of the succession (Karabögürtlen Formation), of probable Late Cretaceous age. Published analyses of unmetamorphosed volcanic rocks from the East Tauride autochthon (Geyik Dağ) are plotted for comparison (Çimen 2018). a Zr/Ti vs. Nb/Y diagram (after Pearce 1996); b Y/Nb vs. Y/ Ta diagram (OIB, E-MORB and N-MORB values are from Sun and McDonough (1989)); c Rock/chondrite vs. rare earth elements; normalising values are from Sun and McDonough (1989); d N-MORB (normal mid-ocean ridge basalt)-normalised multi-element plot (normalising values are from Sun and McDonough 1989); e Th/Yb vs Ta/ Yb diagram (after Pearce 1982); f Nb/Y vs. Zr/Y diagram. Delta Nb indicates relative alkalinity (after Fitton 2007). See text for explanation and interpretation

2007). Where present, the subduction influence (negative $\mathrm{Nb}$ and Ta anomalies) could relate to coeval subduction. However, the subduction influence could also represent derivation from sub-continental mantle lithosphere that was fluxed with subduction fluids during some earlier unrelated subduction event (e.g. Pearce 1982, 1983; Fitton et al. 1991; Gibson et al. 1993; Verma 2009). The latest prior metamorphism that affected the Tauride and Anatolide crustal units was Cambrian, c. 520-530 Ma (Kröner and Şengör 1990; Gürsu and Göncüoğlu 2005; Zlatkin et al. 2013).

\section{Late Palaeozoic volcanic rocks of the East-Tauride carbonate platform}

The Precambrian-Eocene succession of the Eastern Tauride autochthon (Feke area) (Fig. 2) includes a minor occurrence of basaltic extrusive rocks (Dalkılıç 2009). The location is southeast of Develi (near Derebaş1) in south-Kayseri Province (Fig. 2). The volcanics (Paleovolcanite of Metin 1986) are located at the contact of the Late Devonian Gümüşali Formation (Demirtaşl1 1967) and the early Carboniferous Tuzludere Formation (Metin 1983). The Gümuşali Formation is dated by a rich assemblage of conodonts and some brachiopods (Metin 1986), whereas the overlying Tuzludere formation is mainly dated using a diverse brachiopod assemblage (Metin 1986). The volcanics were included in the Late Devonian Gümüşali Formation by Metin (1986), but were later considered to be early Carboniferous, based on regional facies correlations (Dr. Yavuz Bedi, personal communication 2000 to Dalkılıç 2009). Çimen (2018) followed Metin (1986) in assuming a Late Devonian age. The exact age of these volcanics, therefore, remains debatable.

Within the small outcrop, individual lava flows are no more than $30-50 \mathrm{~cm}$ thick and are exposed laterally for several tens of metres. The basalts range from aphyric to plagioclase-pyroxene-phyric. Chemical analysis of five samples shows that these rocks are basaltic, with
near-MORB, to slightly 'enriched' trace element patterns. Immobile element discrimination diagrams indicate the presence of a minor subduction influence (e.g. Nb). The basalts are inferred to have a contemporaneous back-arc basin origin based on subduction geochemical signature (Çimen 2018).

The Tauride autochthon volcanics (Feke area) are compared with the Binboğa unit metavolcanics in Fig. 9. The majority of the samples from both volcanic units are basaltic (Fig. 9a). Four of the Tauride autochthon samples (Feke area) are enriched (E-MORB), similar to several of the Binboğa metavolcanic samples. However, one sample from the Tauride autochthon has a near-MORB composition (Fig. 9b). On the rock/chondrite plot vs. REE plot, the Tauride autochthon samples overlap in composition with the Binboğa metavolcanics but are generally more depleted (Fig. 9c). A similar pattern is present in the rock vs. N-MORB spider plots (Fig. 9d). On the Th/Yb vs. Ya/ $\mathrm{Yb}$ plot, eight of the samples plot within the field of volcanic arc rocks, while two (one from each area) plot near to E-MORB; one plots near MORB (Fig. 9e). On the Nb/Y vs. $\mathrm{Zr} / \mathrm{Y}$ diagram, the samples mainly overlap in composition and are relatively 'depleted' compared to Icelandic basalts (Fig. 9f).

Both sets of volcanic rocks can also be compared with the early Carboniferous Çataloturan unit tuffs. These are more evolved magmatically as they plot in the trachyte and alkali rhyolite fields (Fig. 6i). Their relatively enriched character is confirmed by plotting in the within-plate granite field (Fig. 6j), their marked enrichment in the rock/ chrondrite spider plots and their evidence of plagioclase fractionation (negative Eu) (Fig. 6k).

In summary, two different volcanic compositional groupings are represented within the Tauride platform units, regionally. The first comprises the meta-volcanics of the Late Palaeozoic Binboğa unit and also the Tauride autochthon volcanics (Feke area). Together, these represent a variably fractionated basaltic suite with a common subduction influence (Fig. 6). The second grouping is represented by the tuffs of the early Carboniferous Çataloturan thrust sheet, which represent a variably 'enriched', evolved alkaline suite.

\section{Regional setting of Late Palaeozoic volcanism}

Any interpretation needs to take account of the Late Cretaceous and Cenozoic tectonics which affected the allochthonous Çataloturan thrust sheet and the Binboğa metamorphics (part of the Malatya-Keban platform), related to 


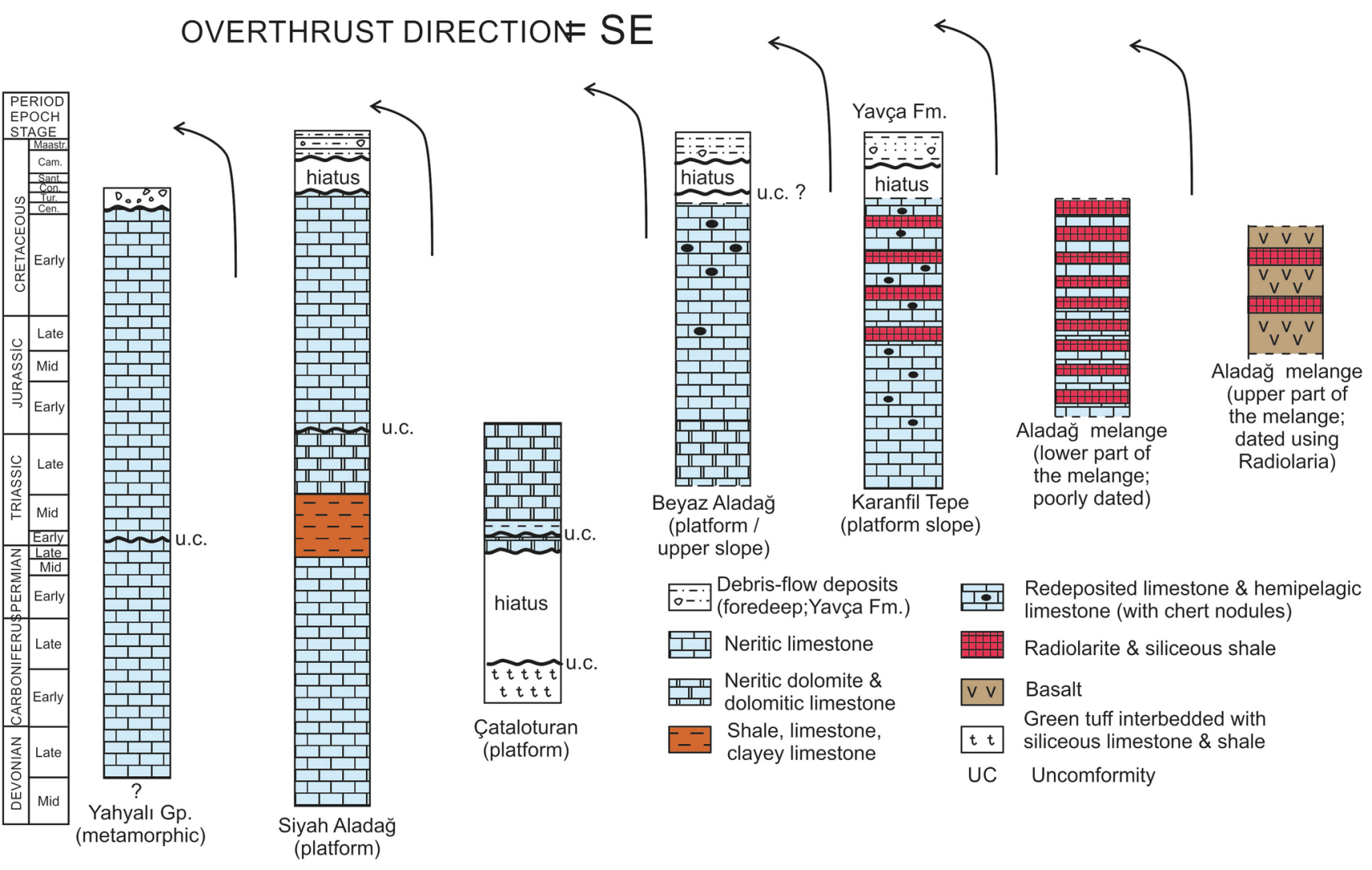

Fig. 10 Structural order of the thrust sheets in the Tauride Aladag massif. The early Carboniferous tuffaceous sediments (Nohutluk Formation) within the Çataloturan thrust sheet are located in the lower part of the overall thrust stack (Tekeli 1981; Tekeli et al. 1984). Note:

Late Cretaceous ophiolite emplacement and ocean-basin closure.

\section{Early Carboniferous tuffaceous sediments: an intra-platform rift}

The early Carboniferous tuffaceous sediments begin just above the lowest exposed level of the succession in the Çataloturan thrust sheet. The Çataloturan thrust sheet is the third lowest thrust sheet making up the Aladağ massif (Fig. 10). Each of these thrust sheets is dominated by Mesozoic Tauride-type shallow-water platform, or platform-slope carbonate successions, with deeper-water distal slope sediments, oceanic sediments and volcanics structurally above (Tekeli et al. 1984; Polat and Casey 1995; Polat et al. 1996; Robertson et al. 2021b). However, only the three lowest thrust sheets include Palaeozoic rocks (Fig. 10).

The thrust sheet that directly underlies the Çataloturan thrust sheet with its tuffaceous deposits is the Siyah Aladağ thrust sheet (Fig. 10). This begins with a mixed neritic carbonate-siliciclastic succession of Late Devonian
An additional, small and discontinuous thrust sheet, mainly made up of Mesozoic platform carbonates, is exposed in the southwest (Minaretepeler thrust sheet), where it underlies the Çataloturan thrust sheet

to Late Permian age, c. 1000 m thick (Blumenthal 1952; Tekeli 1981; Tekeli et al. 1984; Balc1 2010). The succession is typically grey-green in the lower part, to blackish in the upper part. Sandstones are quartz rich. Limestones range from wackestones, to packstones, to grainstones and are locally rich in brachiopods, coral, gastropods, calcareous algae and large foraminifera. The lower part of the succession includes the benthic foraminifera, Nanicella sp. and Eonodosaria sp. together with the brachiopods, Productella subaculeata and Cryptospirifer syringothyriformis of Late Devonian age. The middle part of the succession contains an early Carboniferous fauna (Tournaisian-Visean), including the large foraminifera Archaediscus sp., Mediocris sp., Milerella sp., Neoarchaediscus sp., Fusulinella sp., Schubertella sp., Ozawainella sp. and Pseudostaffella sp., together with the calcareous alga Koninckopora sp. An upward continuation into the late Carboniferous is suggested by the presence of the large foraminifera, Pseudotextularia sp., Triticites sp. and Boultonia sp., together with the calcareous algae Girvanella sp. and Koninckopora sp. The succession includes an interval of pale-coloured, well-sorted quartzarenite (orthoquartzite) (Köşkdere formation), in which 
detrital zircons are mainly of Precambrian age (Ustaömer et al. 2020). Above this, there is a richly fossiliferous interval of Permian shallow-water carbonates, including the Early Permian Girvanella zone, which passes upwards into Triassic shallow-water shelf carbonates and mudrocks, as in the Taurides generally (Tekeli et al. 1984; Ayhan and Lengeranlı 1986). The Siyah Aladağ thrust sheet, therefore, documents a subsiding carbonate platform without evidence of Carboniferous tuffaceous or slope deposits.

Beneath the Siyah Aladağ thrust sheet, there is one more thrust sheet, the regional-scale Yahyalı thrust sheet (Fig. 10). Combining information from the Aladağ and Malatya areas (Tekeli 1981; Tekeli et al. 1984; Ayhan and Lengeranlı 1986; Alan et al. 2007; Balc1 2010), the succession is dominated by dark grey to black, medium to thick-bedded, recrystallised limestone and dolomite, with subordinate quartzarenite (quartzite) and mudrock (metashale and calcschist). Poorly preserved brachiopods, corals, gastropods and calcareous algae suggest a Late Devonian age in the Aladağ area (Tekeli 1981; Tekeli et al. 1984). Overlying medium to thick-bedded, recrystallised limestone, quartzite, dolomite and meta-mudrock contain large foraminifera (fusulinids) of Carboniferous age. The succession continues with Early Permian Girvanella-bearing meta-limestones. Emergence is marked by meta-bauxite in places. The Late Permian is characterised by meta-carbonates with Mizzia. Above further metabauxite and/or a basal conglomerate the Early Triassic is more pelitic, followed by typical Tauride shelf carbonates of Late Triassic to Late Cretaceous age. Tiny carpholite relics (10- to $100 \mu \mathrm{m}$-long fibers) occur within quartz grains indicating that the Yahyalı thrust sheet has undergone HP/ LT metamorphism (Pourteau et al. 2010). The Yahyalı thrust sheet can be generally correlated with the Bolkar Dağ thrust sheet in the central Taurides farther west, which contains glaucophane and fibrous calcite after aragonite, again indicative of HP-LT metamorphism (Pourteau et al. 2010). Similar carpholite-bearing lithologies have been traced for $>600 \mathrm{~km}$ c. E-W across the Afyon zone, within the Anatolide crustal unit (Pourteau et al. 2010).

The Siyah Aladağ thrust sheet and the Yahyalı thrust sheet restore as different parts of a gently subsiding Late Palaeozoic shelf, with variable influxes of neritic carbonate and siliciclastic sediments, largely controlled by a combination of tectonic instability (extension) and sea-level fluctuations. Similar Late Palaeozoic successions (e.g. Gümüşali Formation) are exposed within the relatively autochthonous Geyik Dağ in the eastern Taurides, including the Tufanbeyli area (Göncüoğlu et al. 2004) and the Karsant1-Akdam area (Ünlügenç and Demirkol 1991). Comparable successions also occur in the Bolkar Dağ 1 , central Taurides (Demirtaşlı et al. 1984) and farther west in the Hadim (Aladağ) and Bolkar thrust sheets, as exposed in the Taşkent-Hadim area (Özgül 1984, 1997; Mackintosh and Robertson 2012b).
The Aladağ thrust sheets, including the Çataloturan thrust sheet, are imbricated beneath the over-riding Late Cretaceous supra-subduction zone Pozant1-Karsantı ophiolite (Lytwyn and Casey 1995; Polat and Casey 1995; Parlak et al. 2000). There are two alternative restorations of the thrust sheets making up the Aladağ unit:

(1) In-sequence thrusting. The Aladağ thrust sheets restore from south to north as follows: Yahyalı thrust sheet, Çataloturan thrust sheet, Beyaz Aladağ thrust sheet, Karanfil Tepe unit, followed by the Late Cretaceous Pozant1Karsantı ophiolite and the related Aladağ melange (Tekeli 1981; Tekeli et al. 1984; Polat and Casey 1995; Alan et al. 2007; Robertson et al. 2021b). The HP/LT Yahyalı thrust sheet at the structural base of the thrust stack represents by far the most deeply buried tectonic unit in the region. The ophiolite is not itself imbricated with the platform units and the overlying Aladağ melange (Polat and Casey 1995; Robertson et al. 2021b), suggesting that the imbrication of the unmetamorphosed platform units beneath predated or accompanied the latest Cretaceous ophiolite and melange emplacement. Also, there is an absence of intercalated Eocene 'flysch' which accompanied Eocene thrusting throughout the central Taurides (e.g. Özgül 1984, 1997; MTA 2011). However, post-Cretaceous imbrication cannot be excluded as there are no age-controlling cover units; (2) Out-of-sequence thrusting (i.e. rethrusting). The HP-LT Yahyalı unit originated farthest north and was deeply buried and metamorphosed as the leading edge of the Tauride-Anatolide continent underthrust/subducted northwards. HP-LT metamorphism of the Afyon zone is dated as Early-Middle Palaeocene (65-60 Ma), based on ${ }^{40} \mathrm{Ar}-{ }^{39} \mathrm{Ar}$ geochronology on white mica and multi-equilibrium thermobarometric calculations (Pourteau et al. 2010; Pourteau 2011). The metamorphism was followed by exhumation and re-thrusting over unmetamorphosed, high-level Tauride units (Pourteau et al. 2010; Pourteau 2011). Re-imbrication, probably during the Eocene, finally placed the Tauride units, including the Late Cretaceous Pozant1-Karsantı ophiolite, over the exhumed HP-LT Yahyalı unit. The present structural position could be achieved more easily by back-thrusting of the LP-LT sheets over the HP-LT (Yahyalı) sheets, as mapped in the central Taurides (Özgül 1984, 1997; Mackintosh and Robertson 2012b).

The sedimentology and volcanism of the successions also hint at proximal-distal relations. Quartzose sediments are coarser-grained and more abundant in the Aladağ thrust sheet (relatively proximal), particularly during Late Permian and Late Triassic rifting, compared to the Bolkar Dağ thrust sheet (more distal). Consistent with this interpretation, the Bolkar Dağ thrust sheet includes Late Triassic volcanogenic lithologies related to rifting (Demirtaşlı et al. 1984; Alan et al. 2007; Robertson et al. 2009; Mackintosh and Robertson 2012a, b). 
The balance of evidence suggests that the HP-LT Yahyalı thrust sheet restores to a more northerly location than the LP-LT thrust sheets including the Çataloturan one. The HP-LT vs. LP-LT successions of the Aladağ unit must have been structurally reorganised during the latest Cretaceous or later. However, there is no obvious reason to infer major outof-sequence thrusting within the unmetamorphosed Tauride platform carbonate units. The Çataloturan unit is, therefore, likely to have originated within the Late Palaeozoic carbonate platform prior to the Mesozoic rifting of the Tauride-Anatolide continental crust. The Çataloturan unit is, therefore, restored as an early Carboniferous intra-platform rift. Radiolaria or other pelagic organisms can accumulate in deep-water rift basins assuming that they are open to oceanic currents (e.g. Bernoulli and Jenkyns 1974). Assuming an intra-platform origin, the early Carboniferous alkaline tuffaceous sediments of the Çataloturan thrust sheet restore as a relatively deep-water rift (100 s of $\mathrm{m}$ ). Tuffaceous input progressively waned and the basin had filled with calciturbidites by the end of the Visean. A depositional hiatus ensued before resumption of shallow-water carbonate deposition during the Late Permian. This hiatus contrasts with the successions in the Siyah Aladağ and Yahyalı thrust sheets (Fig. 10). A possible explanation is that the inferred rift was shortened, stratigraphically inverted, uplifted and eroded prior to Late Permian transgression. A similar unconformity, related to contractional tectonics, affects the Konya Complex in the Afyon zone farther west (see below). The Çataloturan thrust sheet might restore to a relatively distal (northerly) location close to the Palaeozoic continental margin. However, an intra-platform rift setting is preferred over a deep-water continental margin setting, mainly because of the evidence of upward shallowing.

In an alternative tectonic model, Göncüoğlu et al. (2007) proposed that the Çataloturan unit formed in a back arc-basin that rifted along the northern margin of Gondwana, related to early Carboniferous southward subduction. The early Carboniferous tuffaceous sediments accumulated on the northern margin of this rifted crust, facing an off-margin magmatic arc (Sakarya arc). Tuff drifted from the arc and settled in the deep-water Çataloturan basin to the south. However, the evolved alkaline nature of the source volcanism is incompatible with a volcanic arc origin. An intra-plate setting is instead indicated by the geochemical evidence (Fig. 6).

\section{Late Palaeozoic Binboğa meta-volcanics: an extensional setting}

The Late Palaeozoic alkaline meta-volcanics of the Binboğa metamorphic unit are also indicative of a within-plate setting, based on the geochemical evidence (Fig. 9). The localised presence of intraformational debris-flow deposits is consistent with an unstable, mixed carbonate-siliciclastic shelf setting. There is no evidence of deep-water conditions (e.g. meta-chert), in contrast to the alkaline tuffs of the Çataloturan thrust sheet.

The palaeogeography of the Late Palaeozoic within-plate volcanism depends on the palinspastic restoration of the Taurides vs. the Anatolides. There are two main alternatives:

In the first alternative, the Binboğa (Malatya) Late Palaeozoic volcanics erupted in an intra-platform setting, to the north of both the Tauride autochthon (Geyik Dağ) and the allochthonous Tauride Munzur platform (MTA 2011). The Binboğa (Malatya) metamorphics correlate with the HP-LT Afyon zone (Anatolides) of the central and western Taurides. The Afyon zone restores to the north of the unmetamorphosed Tauride thrust sheets (Aladağ (Hadim) of the central and western Taurides (Özgül 1984, 1997; Göncüoğlu et al. 2003; Okay et al. 2006; Pourteau et al. 2010, 2013, 2016; Mackintosh and Robertson 2012b). The HP-LT metamorphism affecting the Anatolides generally relates to northward underthrusting/subduction of the Tauride-Anatolide crustal block during latest Cretaceous-early Cenozoic (Candan et al. 2005; Pourteau et al. 2010, 2013, 2016 and references). In this alternative, the Binboğa metamorphics restore to the north of the unmetamorphosed Tauride units. The Late Cretaceous ophiolites and related accretionary melanges were emplaced southwards over the Binboğa/Malatya crust (Malatya-Keban platform), directly onto the Tauride platform carbonates to the south (Munzur platform).

In the second alternative, the Binboğa metamorphics between the Tauride autochthon (Geyik Dağ) to the south and the unmetamorphosed Munzur platform to the north. The field relations indicate that the Binboğa (Malatya) metamorphics are to the south of, and structurally beneath, the Munzur platform, with the ophiolites/accretionary melanges above (Perinçek and Kozlu 1984; Robertson et al. 2006, 2013, 2021a; Alan et al. 2007; Bedi et al. 2009; Bedi and Yusufoğlu 2018). Conceivably, the present structural organisation was achieved by thrusting of the Binboğa/ Malatya metamorphic crust southwards over the Tauride carbonate platform (Munzur limestones) during the latest Cretaceous, followed by re-thrusting to position the Munzur platform above the Binboğa/Malatya metamorphics. Some re-thrusting did indeed take place during the Eocene and/ or Miocene (Perinçek and Kozlu 1984; Bedi et al. 2009; Robertson et al. 2013, 2021a), but this seems unlikely to have completely reorganised the stacking order of the major tectonic units in the eastern Taurides. On the other hand, the Binboğa/Malatya crust was intruded by granitic rocks (Baskil granitoids), dated radiometrically as $88-82 \mathrm{Ma}$ (Santonian-Campanian) (Parlak 2006; Rızaoğlu et al. 2009; Karaoğlan et al. 2016). These granitoids are interpreted to relate to northward subduction of oceanic crust to the south (Rheic ocean) implying a relatively southerly position of 
the Binboğa/Malatya crust (Malatya-Keban platform) before southward ophiolite emplacement (c. 75-68 Ma). In alternative two, a deep zone of underthrusting/subduction separated the Malatya-Keban platform in the south from the Munzur platform to the north. The Malatya-Keban units represented separate platforms, perhaps with a basin between that collapsed and deeply underthrust northwards to form the HP-LT Binboğa (Malatya-Keban) metamorphics. The metamorphism is inferred to be Late Cretaceous because the youngest succession (Karaböğürtlen Formation) in the Malatya-Keban platform is Late Cretaceous (Cenomanian), whereas the unconformable sedimentary cover begins in the Maastrichtian (Kemaliye and Gündüzbey formations) (Perinçek and Kozlu 1984; Bedi et al. 2009; Robertson et al. 2013, 2021a; Bedi and Yusufoğlu 2018). In the second alternative, the Late Palaeozoic Binboğa volcanics erupted in an intraplatform setting adjacent to the exposed Tauride autochthon (Geyik Dağ), where geochemically similar magmatic rocks are locally present (Feke area), as shown in Fig. 11. The palaeogeography of the central and eastern Taurides differed markedly in this preferred alternative.

\section{Tectonic development of the N Gondwana continental margin}

The tectonic-magmatic setting of the north-Gondwana continental margin also needs to take account of the late Carboniferous melanges and granitic rocks within the Afyon zone, and also the unmetamorphosed melanges in the Lycian nappes (Teke Dere unit) and in the Karaburun Peninsula (eastern Aegean) (Fig. 2).

\section{Konya melange and granitic rocks (Anatolides)}

In central-southern Anatolia, late Cretaceous accretionary melanges and ophiolites are unconformably underlain by the Late Palaeozoic-Early Mesozoic, tectonically assembled Konya Complex, within the Afyon zone (Anatolides) (Fig. 2). The Afyon zone is proposed to be a fragment of the Eurasian active continental margin that accreted to the Tauride crustal block during latest Triassic (see Fig. 1bii) (Stampfli et al. 2001; Eren et al. 2004; Moix et al. 2008). However, the Afyon zone is also interpreted as part of the Tauride-Anatolide continental block which remained close to Gondwana (e.g. Şengör and Yılmaz 1981; Göncüoğlu et al. 2000, 2003; Okay et al. 2006; Göncüoğlu 2011; Robertson et al. 2009; Candan et al. 2016). The main evidence for the two alternative interpretations is reviewed below taking account of recent geochronological data.

The exposed succession in the Konya Complex (Fig. 12) begins with latest Silurian-Early Devonian shelf carbonates (Bozdağ Formation), including red nautiloid limestones that can be correlated with the Eastern Tauride autochthon (Geyik Dağ) (Göncüoğlu et al. 2000, 2001, 2004). The succession continues with Middle-Late Devonian Amphiphora limestones, as in the relatively autochthonous carbonate platform succession, and then passes into early Carboniferous neritic limestones, rich in corals, fusulinids, algae and crinoids (Özcan et al. 1990; Eren 1993, 1996; Eren et al. 2004; Göncüoğlu et al. 2001, 2004). Locally, the carbonate platform succession (which is commonly inverted) passes stratigraphically upwards from Visean (early Carboniferous) to Serphukovian-Bashkirian (early-late Carboniferous) facies (Göncüoğlu et al. 2001; Göncüoğlu, 2011). There is no evidence of volcaniclastic input in contrast to the early Carboniferous Tauride Çataloturan succession.

The carbonate platform shows evidence of drastic subsidence, collapse and break-up, followed by the emplacement of both locally derived and exotic blocks, within a darkcoloured, organic-rich, siliciclastic matrix (Halıc1 Formation of Özcan et al. (1988, 1990); Sizma Group of Eren (1993, 1996); Konya melange of Robertson and Ustaömer (2009a, 2011) and Löwen et al. (2020) (Fig. 12). In decreasing order of abundance, the main blocks in the melange are neritic limestone of Silurian-Carboniferous age, black chert and pelagic carbonate of Silurian-Carboniferous age, diabase/ microgabbro and also aphyric to feldspar-phyric basalt, with WPB and MORB tectonic affinities (Kurt 1996; Göncüoğlu et al. 2007; Robertson and Ustaömer 2009a, 2011; Akal et al. 2012). In places, the cherts are spatially associated with blocks of basaltic lava, suggesting that they were derived from the same deep-sea/oceanic setting (Robertson and Ustaömer 2009a, 2011). The matrix of the melange is mainly meta-mudrock, meta-sandstone turbidites (up to thick bedded) and subordinate, lenticular, matrix-supported meta-siliciclastic conglomerates (e.g., pebbly debris-flow deposits). The black meta-cherts have a generally terrigenous composition (Kurt 1997; Eren and Kurt 2000). Point-counting indicates that the main lithologies are quartzarenite, subarkose, sublitharenite and quartzwacke (Robertson and Ustaömer 2011; Löwen et al. 2020). In addition to common metamorphic lithoclasts, there are rare clasts of meta-basic and meta-felsic volcanic rocks (Robertson and Ustaömer 2011). Whole-rock geochemical data for meta-sandstones point to predominantly felsic source rocks (Löwen et al. 2020).

The matrix of the melange includes meta-mudrocks with siliceous microfossils (Muellerisphaerida) and also pelagic limestones with deep-water conodonts of Late Silurian (Wenlock)-Early Devonian age (Göncüoğlu and Kozur 1998; Göncüoğlu et al. 2001). The siliciclastic matrix is locally dated as early Carboniferous (Visean), based on rare interbedded limestones with benthic foraminifera of this age (Göncüoğlu et al. 2001), although these could be 


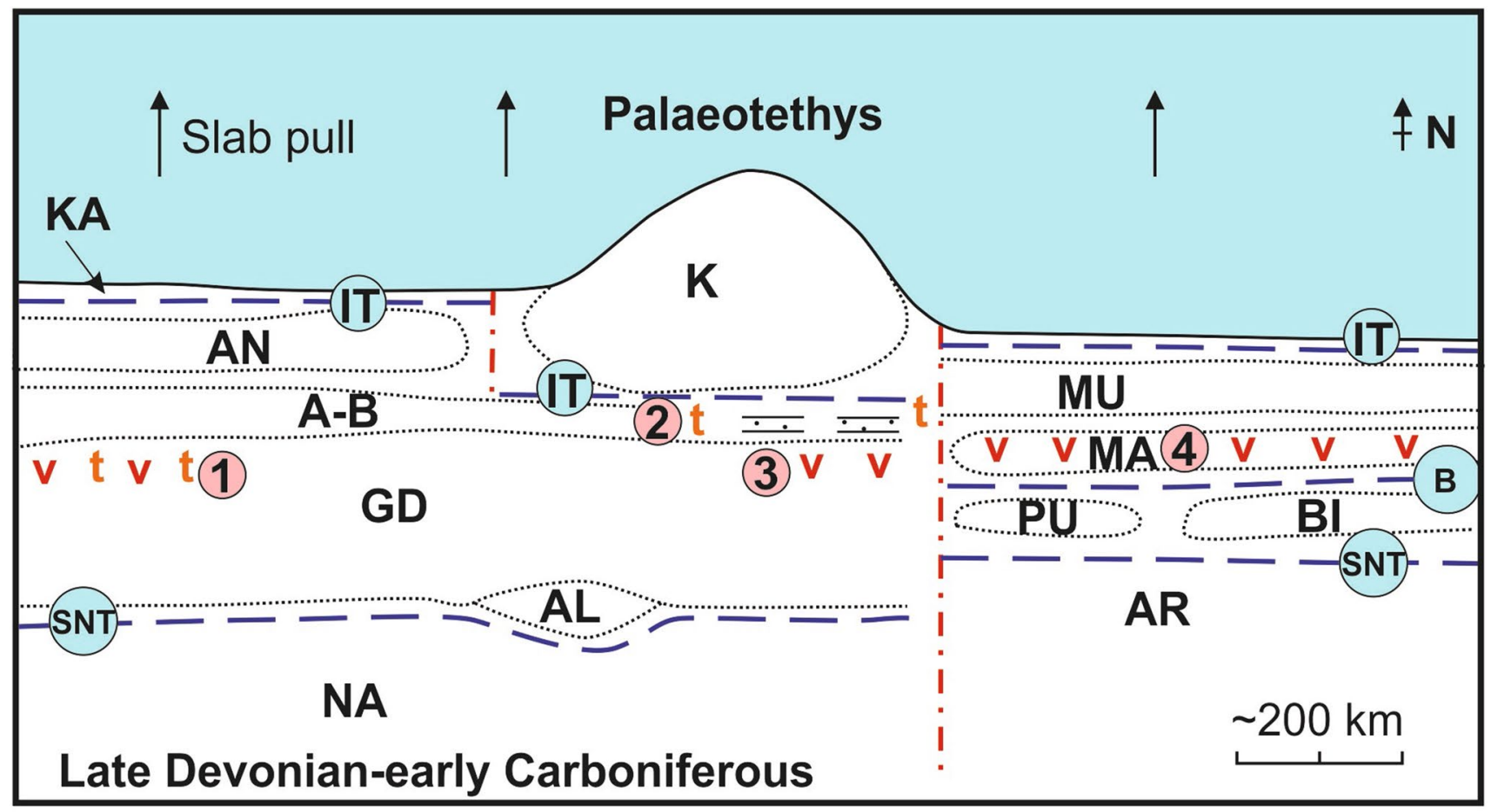

\section{KEY}

A-B Aladağ \& Bolkardağ thrust sheets

AL Alanya crustal block

AN Anatolides crustal blocks

AR Arabian continent

BI Bitlis crustal block

GD Geyikdağ crustal block

KA Karakaya crustal sliver

K Kırşehir crustal block

MA Malatya crustal block

MU Munzur crustal block

NA North African continent

PU Pütürge crustal block

(1) Geyikdağ (Sultandağ), Central Taurides

Future oceanic crust

(2) Çataloturan thrust sheet (Aladağ), Central Taurides

(3) Geyikdağ (Feke area, Eastern Taurides)

(4) Binboğa metamorphics (Malatya region, Eastern Taurides)

Fig. 11 Tentative restoration of the north margin of Gondwana in the eastern and central Taurides during the Devonian to mid-Carboniferous showing the intra-plate volcanism (note: the western Taurides including the Menderes massif are excluded). The reconstruction depends on how the Late Cretaceous and Eocene thrusting events are restored (see the text for alternatives). Also, possible relative strikeslip displacements of the different crustal unts are not considered 
Fig. 12 Summary tectonostratigraphy of the Late Palaeozoic-Early Mesozoic Konya Complex. See text for explanation and data sources

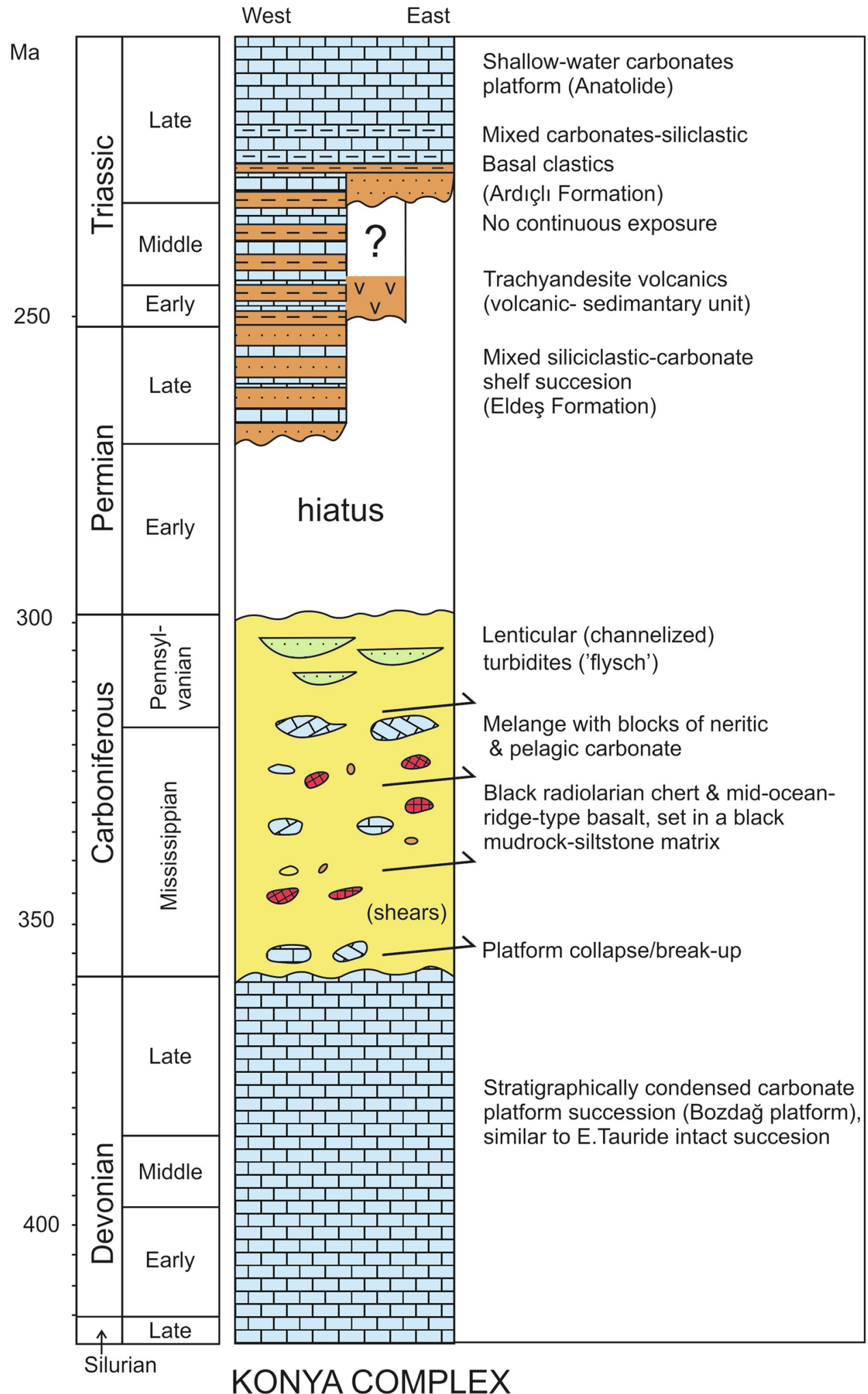


redeposited. Detrital zircons from six sandstone from the melange are significantly older than the biostratigraphically determined age of the melange matrix (Löwen et al. 2020; Ustaömer et al. 2020).

Löwen et al. (2020) also report a unit of 'meta-flysch' above the melange and also above the adjacent Late Palaeozoic carbonate platform (Bozdağ unit). The 'meta-flysch' comprises well-bedded meta-mudstones, meta-siltstones and meta-sandstones, locally with plant material and common meta-volcanic fragments. Petrographically, the 'meta-flysch' is generally similar to the meta-sandstones of the melange beneath, although richer in meta-volcanic clasts (Löwen et al. 2020). Detrital zircons from one sample yielded the youngest ages (spot ages) of $326.3 \pm 5.3$ and $328.3 \pm 3.8 \mathrm{Ma}$ (Serpukhovian). Another sample provided three late Carboniferous spot ages (Löwen et al. 2020). Löwen et al. (2020) assumed a late Carboniferous-early Permian (PennsylvanianCisuralian) age for the 'meta-flysch', based mainly on the youngest detrital age data present. Comparable, low-grade metamorphosed turbidites occur within the Karaburun melange (Karaburan Peninsula) (Fig. 2) have also yielded detrital zircons with late Carboniferous-Early Permian youngest ages (Löwen et al. 2017).

The oldest cover of the Devonian-Carboniferous Konya Complex is a shallow-marine mixed siliciclastic-carbonate succession exposed in the east (Eldeş Formation) (Özcan et al. 1988, 1990; Robertson and Ustaömer 2009a, b). In the west, the Konya melange is locally overlain, unconformably, by Early Triassic meta-trachyandesites (Volcanic-sedimentary unit) (Akal et al. 2012). Elsewhere in the same general area, volcanics are absent and the Konya Complex is unconformably overlain, above a basal conglomerate, by non-marine to shallow-marine siliciclastic sediments (Ardıçlı Formation) (Özcan et al. 1988, 1990; Robertson and Ustaömer 2009a, b). Based on the youngest detrital zircons present, these siliciclastics are no older than Late Triassic (Löwen et al. 2020). In one area, red metaclastics, correlated with the Ardıçl Formation, are interbedded with meta-volcanics (Kadınhanı meta-trachyandesites), with a crystallisation age of $220.24 \pm 0.7 \mathrm{Ma}$ (Norian) (Güven et al. 2012; Ustaömer et al. 2016b). In addition, zircons from two metarhyolites (İlgin area) are dated as Middle Triassic (230-229 Ma) by the shrimp method (Özdamar et al. 2013). Phengites from the same metarhyolites gave Palaeocene Ar-Ar plateau ages ( 63 Ma), interpreted as the timing of the regional HP-LT metamorphism affecting the Afyon zone. The overall succession passes upwards into lenticular shallow-marine carbonates and siliciclastics that in turn grade into Late Triassic-Early Cretaceous platform carbonates, typical of the Afyon zone generally (Eren 1993; Özcan et al. 1988, 1990; Göncüoğlu et al. 2007; Robertson and Ustaömer 2009a, b).
In addition, late Carboniferous (320-310 Ma) (Moscovian-Bashkirian) granitic rocks cut the Afyon zone in its type area, c. $200 \mathrm{~km} \mathrm{NW}$ of the Konya melange (Candan et al. 2016; Ustaömer et al. 2020). Also, blocks of granitoid rocks, loosely dated by the $\mathrm{K}-\mathrm{Ar}$ method as Carboniferous-Devonian, occur within the Mersin melange on the southern slopes of the Taurus Mountains (Parlak and Robertson 2004), although these require more accurate dating to allow proper interpretation.

Most of the sandstone samples from the matrix of the Konya Melange (Löwen et al. 2020; Ustaömer et al. 2020), like the Carboniferous sandstones of the Siyah Aladağ thrust sheet in the eastern Taurides (Ustaömer et al. 2020), contain detrital zircons with $\mathrm{U}-\mathrm{Pb}$ age profiles that are consistent with an ultimately NE-Gondwana provenance. On the other hand, there are some Carboniferous zircons, and Devonian zircons are relatively abundant in the sandstone turbidites ('meta-flysch') from above the melange (Löwen et al. 2020). The likely source of these meta-sandstones, according to these authors, is Devonian granitic rocks of the Biga Peninsula in NW Turkey (Sakarya Zone), potentially including the Çamlık granodiorite (398 $\pm 1 \mathrm{Ma}$ ) (Okay et al. 1996, 2006; Aysal et al. 2012) and, or the Karacabey Pluton (394 \pm 3 Ma and 396 $\pm 4 \mathrm{Ma}$ (Sunal 2012) and the Güveylerobası granite $(371.2 \pm 2.3 \mathrm{Ma})$ (Ustaömer et al. 2016). The Devonian granites could relate to southward subduction of the Rheic (Rheno-Hercynian) ocean to the north (Okay et al. 1996, 2006; P.A. Ustaömer et al. 2012; Aysal et al. 2012; Sunal 2012; Okay and Topuz 2017).

On the other hand, Ustaömer et al. (2020) note that the $\mathrm{Lu}-\mathrm{Hf}$ isotopic compositions of the Carboniferous zircons of the Triassic Tauride sandstones plot within the distribution of the Afyon Zone granites (studied by these authors), consistent with the Anatolide crustal block as a possible source for the zircons in these sandstones. Although Devonian granites are unknown in the Anatolide crustal unit, inherited Devonian zircons occur within the Carboniferous metagranites of the Afyon zone (Candan et al. 2016; Ustaömer et al. 2020). Specifically, Devonian zircon cores occur in two samples of Carboniferous Anatolide granites, as analysed by Ustaömer et al. (2020). A Devonian igneous source could, therefore, exist within the Afyon zone crustal block. However, it is unclear whether the Late Palaeozoic granites of the Afyon zone were exhumed and eroding during the late Carboniferous formation of the Konya Complex. At present, therefore, the source of the Mid-Devonian magmatic zircons remains uncertain.

\section{Teke Dere (Lycian Nappes)}

Fragmentary units of unmetamorphosed Carboniferous-Permian shallow to deep-marine sedimentary rocks and volcanic rocks are exposed near the base of the Lycian nappes (Tavas 
nappe) in the western Taurides (Fig. 2). The Lycian nappes represent unmetamorphosed fragments of the Tauride carbonate platform (De Graciancky 1972; Şengör and Yılmaz 1981; Kozur et al. 1998; Collins and Robertson 1998; Pourteau et al. 2013). The lowest thrust sheet (Karadağ thrust sheet), which restores furthest south, assuming in-sequence thrusting, comprises a Tauride-type Carboniferous-Triassic succession (De Graciansky 1972; Şenel et al. 1989; Collins and Robertson 1998, 1999; Moix et al. 2013). The overlying Teke Dere unit is made up of four main lithological associations: (1) volcanic build-up and associated shallow-water bioclastic carbonates; (2) marginal facies of a volcanic build-up of shallow to deepwater origin; (3) Structurally overlying, mainly deep-water pelagic sediments (pelagic limestone; radiolarian chert; basalt; sandstone turbidites) and (4) localized Permian shelf carbonates (Kozur et al. 1998; Göncüoğlu et al. 2000; Stampfli and Kozur 2006; Robertson and Ustaömer 2009b, 2011).

The volcanic build-up (Çatakdere Formation) exposes basalt (mainly trachybasalt), passing upwards into volcanogenic conglomerate, with well-rounded clasts and shallow to deep-water slope carbonates (Kozur et al. 1998; Robertson and Ustaömer 2011; Moix et al. 2013). Calcareous algae and foraminifera, notably fusulinids, within interbedded sediments date the lavas as late Carboniferous (Moscovian-Kasimovian), whereas the overlying slope facies are late Carboniferous-Early Permian (latest Moscovian, Kasimovian), to Early Permian (Gzhelian-early Cisuralian) (Kozur and Şenel 1999; Vachard and Moix 2011; Moix et al. 2013). Geochemically, the extrusives (Çatakdere Formation) are alkaline, within-plate basalts (Robertson and Ustaömer 2011; Moix et al. 2013). A structurally overlying tectonic slice complex (Robertson and Ustaömer 2009a, 2011) or olistostrome ('İncirbeleni Formation') (Kozur et al. 1998; Vachard and Moix 2011; Moix et al. 2013) includes MOR basalt (Stampfli and Kozur 2006), with Carboniferous intra-pillow sediment (Kozur et al. 1998; Moix et al. 2013).

The upper composite unit ('İncirbeleni Formation') is interpreted as early Carboniferous oceanic crust, deep-sea siliceous sediments and distal calciturbidites (seamount-derived?) that accreted, together with sandstone turbidites, at a subduction trench. The late Carboniferous-earliest Permian volcanic-sediment units are interpreted as the remains of a late Carboniferous seamount and capping carbonate platform that collapsed during latest Carboniferous-earliest Permian, shedding debris into deep water, before being accreted in an active margin setting (Stampfli and Kozur 2006; Robertson and Ustaömer 2009b, 2011). The volcanic build-up subsided relatively slowly which could favour an origin as part of a rifted off-margin crustal block rather than a typical ocean-ocean seamount.

In summary, the Teke Dere unit is interpreted as part of a Palaeotethyan accretionary complex, which included the Konya Complex. The accretionary terrane included the Karaburun melange (Karaburun) and other outcrops in the eastern Aegean (notably Chios) which will not be considered here (e.g. Papanikolaou and Sideris 1983; Robertson and Pickett 2000; Zanchi et al. 2003; Meinhold et al. 2008; Robertson and Ustaömer 2009b, 2011; Löwen et al. 2017; Ustaömer et al. 2020).

\section{Rheic ocean-Palaeotethyan tectonic- magmatic relations}

The magmatic rocks related to the tectonic development of both the Rheic and Palaeotethyan oceans broadly range from Cambrian to early Carboniferous (500-340 Ma) and include the Cambro-Ordovician (Uğurcan et al. 2019), Silurian (Karsli et al. 2020; Topuz et al. 2020) and Devonian granites in the Pontides (Okay et al. 2006; Aysal et al. 2012; Sunal 2012; Ustaömer et al. 2016a, b). Specifically, the oldest known meta-igneous host rocks in the Pontides are Cambrian-Early Ordovician meta-granites and metagabbros of the central Sakarya crustal unit (Uğurcan et al. 2019). During the Late Silurian, Palaeotethys opened by rifting of Gondwana and then closed in western and central Europe by early Carboniferous time, creating the Variscan orogen (e.g. Vai 2003; von Raumer et al. 2003; Okay et al. 2006; Cocks and Torsvik 2006; Stampfli and Kozur 2006; Kröner and Romer 2013; Okay and Topuz 2017; Wu et al. 2020).

In many interpretations, the closure of the Rheic ocean was achieved by southward subduction, coupled with the opening of Palaeotethys farther south (Stampfli and Borel 2002; von Raumer et al. 2003; Cocks and Torsvik 2006; Rolland et al. 2016; Rolland 2017). In one model, the subsequent early Carboniferous (340-330 Ma; mainly Visean) granitic magmatism of the circum-Black Sea region, including the Sakarya arc, extending at least as far east as the Caucasus, relates to northward subduction of Palaeotethys (Ustaömer et al. 2013; Rolland et al. 2016; Okay and Topuz 2017). Subduction continued during the late Carboniferous-Permian based on evidence from adjacent regions (e.g. Bulgaria) (Bonev et al. 2019). In another model (Dokuz et al. 2011, 2015), Palaeotethys restores to the north of the Rheic ocean. Rifting of a 'peri-Laurussian terrane' above a northward-subducting Rheic ocean generated Palaeotethys as a marginal basin along the southern margin of Laurussia during Late Silurian-Early Devonian. Driven by southward subduction of the Rheic Ocean, the 'peri-Laurussian terrane' drifted southwards and collided with the north-Gondwana margin, triggering the Variscan orogeny during Late Devonian-early Carboniferous (Dokuz et al. 2011, 2015). More evidence is needed to test the above Rheic-Palaeotethys alternatives.

In one of the tectonic models (Fig. 1aii), Palaeotethys closed by southward subduction, creating the Sakarya arc 
within, or close to, the northern borderland of Gondwana (Şengör and Y1lmaz 1981, 2003, 2007; Şengör et al. 1984; Göncüoğlu et al. 2000; Dokuz et al. 2011; van Hinsbergen et al. 2020). Göncüoğlu et al. (2007) interpreted the Sakarya arc as an oceanic arc that was separated from Gondwana by a marginal basin (or trapped oceanic crust), possibly similar to the modern Aleutian arc (e.g. Kelemen et al. 2003). The host rocks of the Sakarya crustal unit as a whole are metaigneous rocks, quartzo-feldspathic schists, gneisses and amphibolites, without ophiolitic rocks (e.g. P.A. Ustaömer et al. 2012; Karslı et al. 2016; Okay and Topuz 2017). The available evidence, therefore, suggests a continental rather than oceanic basement to the Sakarya crustal unit and thus that the Sakarya arc formed along a continental borderland.

In other tectonic models (Fig. 1bii, cii) the Sakarya arc formed by northward subduction beneath, or adjacent to, the southern margin of Eurasia (Robertson and Dixon 1984; Stampfli and Borel 2002; Topuz et al. 2010; P.A. Ustaömer et al. 2012; Okay and Topuz 2017; Barrier et al. 2018). Northward subduction created the early Carboniferous (320-330 Ma) granitic rocks of the Sakarya zone and those of late Carboniferous-Permian age more widely in the circum-Black Sea region (Okay and Topuz 2017; Aysal et al. 2018; Bonev et al. 2019). No definite evidence has so far been identified of a Late Palaeozoic suture zone and/ or subduction-accretion complex related to southward subduction between the Pontides and Eurasia, as in model 1 (Fig. 1aii, aiii). Northward subduction is also inferred in the Caucasus, farther east during the Late Palaeozoic (Adamia et al. 2003, 2011; Rolland et al. 2016; Rolland 2017).

Assuming overall northward subduction of Palaeotethys (Fig. 1b,c), there are three main options to explain the late Carboniferous inferred accretionary origin of the melanges (Konya Complex, Teke Dere, Karaburun Peninsula), and also the late Carboniferous granites of the western Afyon zone.

The first option is accretion of Eurasian fore-arc crust to Gondwana during latest Triassic (Eren et al. 2004; Moix et al. 2008, 2011) (Fig. 1bii-biii). The Sakarya arc rifted and drifted southwards until it collided with Gondwana during latest Triassic. However, problems include the following: (1) the absence of a Triassic subduction complex or volcanic arc accreted to Gondwana; (2) the correlation of the Konya Complex Late Palaeozoic platform (Bozdağ unit) with the Tauride autochthon (Geyik Dağ); (3) the absence of a Triassic collisional (flexural) foreland basin; (4) the Southern Neotethys began to open during the Late Triassic (e.g. Robertson et al. 2012; Barrier et al. 2018), such that the Tauride crustal block was still located close to Gondwana rather than having drifted away northwards towards Eurasia; (5) modern and ancient intra-continental margin basins typically remain narrow rather than developing into wide ocean basins (e.g.
Black Sea; Tyrrhenian Sea; Aleutians back-arc basins; Japan Sea) (e.g. Sdrolias and Müller 2006, and references).

The second option is that the late Carboniferous accretionary melange and the 320-310 Ma (Moscovian-Bashkirian) granitoid rocks cutting the Afyon zone both relate to southward subduction; this implies double, northward and southward subduction at least during the late Carboniferous (Robertson et al. 2009a, b, 2012; Candan et al. 2016; Ustaömer et al. 2020) (Fig. 1cii). In this interpretation, Palaeotethys narrowed westwards from the Turkish region to the Balkan region (e.g. Cocks and Torsvik 2006). Closure was complete in the Dinaride region (North Macedonia, Croatia, Serbia, Slovenia) by the end of the Carboniferous. For example, in Slovenia late Carboniferous clastics include pebbles derived from the Variscan basement (Pamić and Jurković 2002). Palaeotethys existed as westward-narrowing gulf during the late Carboniferous in the (restored) south and central Aegean region (Zanchi et al. 2003). Contraction of Palaeotethys in a confined oceanic space farther east, in western Turkey (Afyon zone), then triggered southward subduction beneath Gondwana, creating a short-lived late Carboniferous active margin with melange accretion (Robertson et al. 2012; Ustaömer et al. 2020) and localised granitic intrusion (Candan et al. 2016; Ustaömer et al. 2020). Southward subduction ended when collision intensified prior to Early Permian. During the Permian, there was a switch to crustal extension along the entire north-Gondwana margin.

The third, related option, also involves collision of Gondwana and Eurasia in the west (e.g. Aegean-Balkan region) during the late Carboniferous. This created a broad east-facing Palaeotethyan gulf. Subduction of Palaeotethys became westwards allowing granitic magmatism to intrude both Eurasian crust in the northwest and more locally Gondwana crust (Afyon zone) in the southwest (Okay and Topuz 2017). Options 2 and 3, above fit the available evidence better than option 1. More evidence is needed for the late Carboniferous palaeogeography of the Aegean region to evaluate options 2 and 3.

\section{Late Palaeozoic volcanism along the north-Gondwana borderland}

In the light of the above regional discussion, we now consider the implications of the new chemical data for the Binboğa (Malatya) and Feke unit (Tauride autochthon) volcanism. The Binboğa and Feke units could represent remnants of essentially the same Late Palaeozoic extensional magmatic province (Fig. 11). The Binboğa unit volcanism could have been the source of the Çataloturan unit tuffaceous sediments, distributed generally westwards towards the rift depocentre. However, it is also possible that the two alkaline volcanic occurrences relate to eruptions in different 
Fig. 13 Alternative tectonic settings of the early Carboniferous alkaline tuffaceous sediments (Nohutluk Formation; Aladağ unit) and the Late Palaeozoic meta-volcanics of the Binboğa (=Malatya) metamorphic unit. a Small plume with northward subduction beneath Eurasia; b rifting related to northward subduction beneath Eurasia; slab-pull causes extension along the N Gondwana continental margin; $\mathbf{c}$ back-arc rift above a southward-dipping subduction zone; $\mathbf{b}$ is preferred (see text). Note: the restored positions of the early Carboniferous alkaline tuffaceous sediments and the Late Palaeozoic meta-volcanics are suggested in Fig. 11, implying substantial palaeogeographic and tectonic differences between the central and eastern Taurides
S

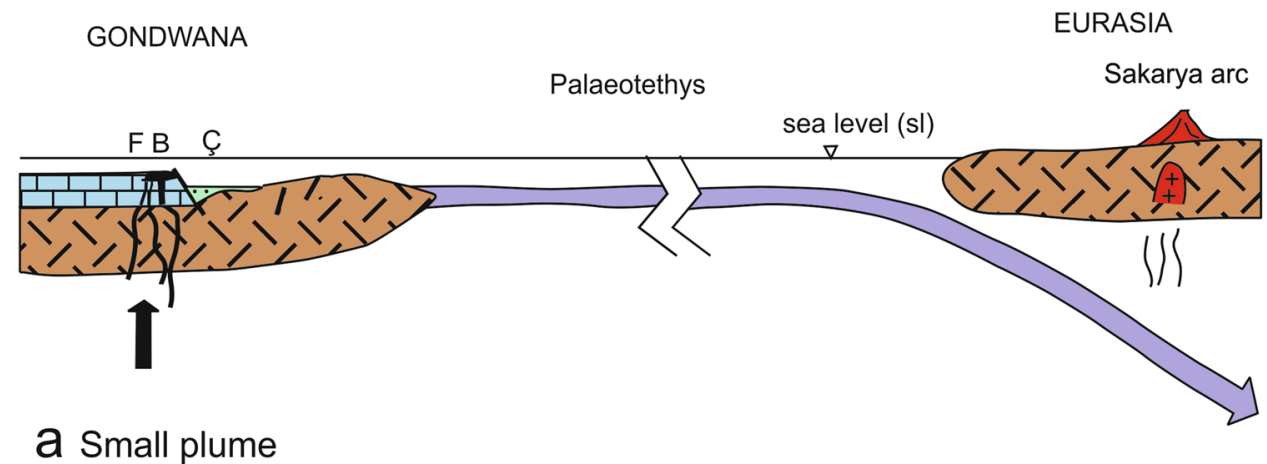

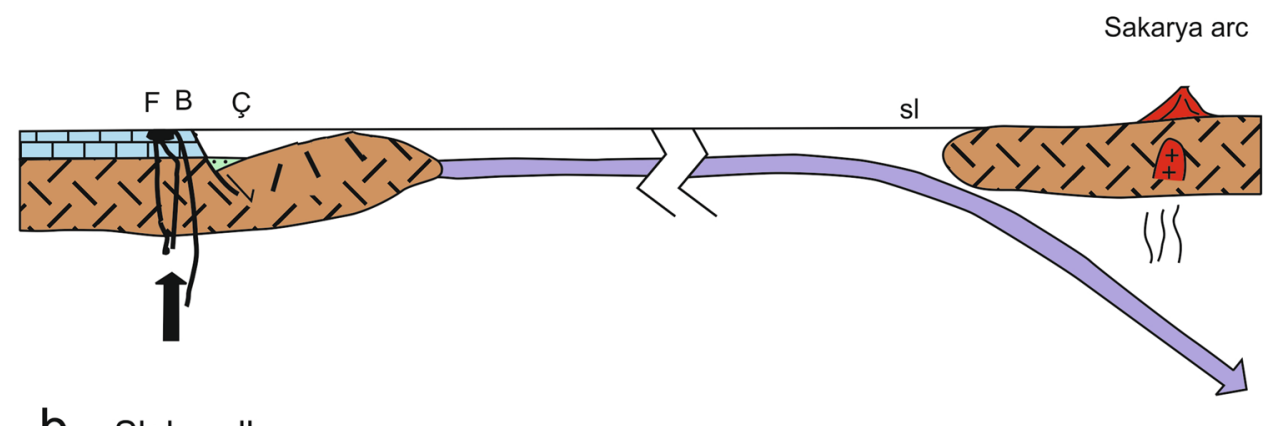

b Slab-pull

back-arc arc

basin arc passive margin

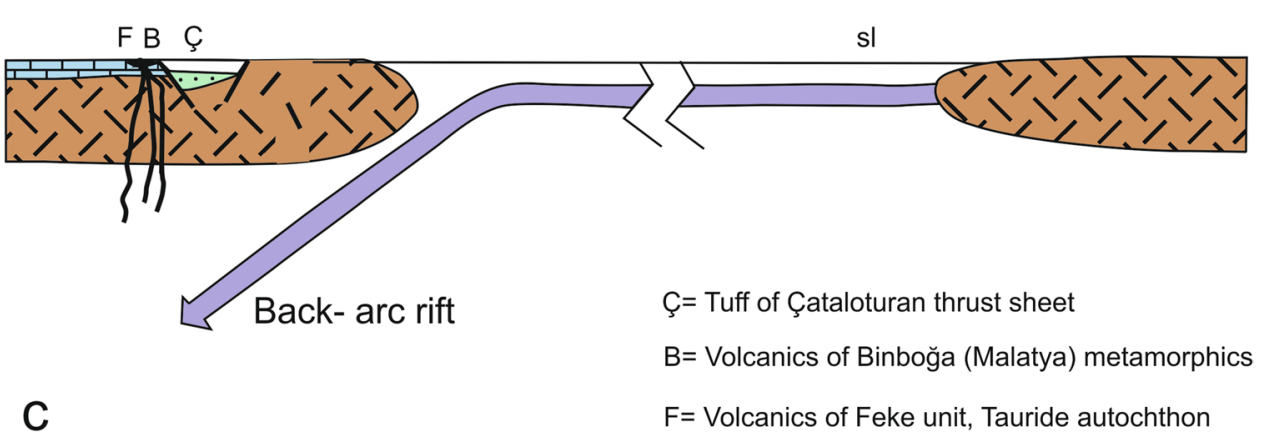

extensional basins at different times. Late Palaeozoic intraplate volcanism, mostly Devonian, is also widely distributed farther east, in Iran (Ruttner 1991; Romer et al. 2001; Wendt et al. 2002; Gharaire et al. 2004), suggesting that such alkaline volcanism was widespread within the north margin of Gondwana.

In the regional setting, as inferred above, the early Carboniferous (Late Tournaisian-Late Visean; c. 340-350 Ma) alkaline volcanism of the Çataloturan thrust sheet and the Late Palaeozoic less 'enriched' meta-volcanics in the Binboğa metamorphic unit have four potential origins:
First, the alkaline volcanics could represent smallscale, relatively shallow-level plume-driven magmatism (e.g. Pik et al. 2006) (Fig. 13a). However, this seems unlikely because the volcanism and tuffs are distributed for $>500 \mathrm{~km}$, generally east-west, approximately parallel to the restored north margin of Gondwana (Fig. 11).

Second, the Devonian-early Carboniferous rifting relates to slab-pull, assuming Palaeotethys subducted northwards beneath Eurasia (Figs. 11, 13b). Slab-pull could have re-activated structural weaknesses within the north margin of Gondwana to form a $>500 \mathrm{~km}$-long east-west volcanically active rift. This is our preferred 
option because it is consistent with the regional geological evidence.

Third, the alkaline volcanism could relate to southward subduction beneath Gondwana, possibly as a Carboniferous back-arc basin (Fig. 13c). Both the Binboğa unit metavolcanics and the Tauride autochthon volcanics (Feke unit) commonly exhibit a subduction influence (i.e., negative $\mathrm{Nb}$ and $\mathrm{Ta}$ anomalies). However, the subduction influence could alternatively have been derived from melting of sub-continental mantle lithosphere (Neoproterozoic-Cambrian), combined with continental crust 'contamination' and variable fractionation. There is evidence of a subduction influence within continental rift volcanics, unrelated to coeval subduction, in many regions of the world (e.g. Fitton et al. 1991; Kempton et al. 1991; Romer et al. 2001; Robertson 2007; Verma 2009; Robertson et al. 2021b). There is no evidence of contemporaneous early Carboniferous arc volcanism, for example arc-derived fallout tuff within the Tauriderelated crust, the Konya Complex, or the Teke Dere unit, located farther north towards Palaeotethys. The obvious candidate for tuff derived from a north-Gondwana continental margin arc, i.e. the Çataloturan unit (Göncüoğlu et al. 2007), is alkaline without subduction influence.

Fourth, the early Carboniferous Çataloturan unit alkaline volcanism might relate to tuff dispersal from seamounts located within Palaeotethys to the north. This would be consistent with the evolved, alkaline volcanism but is otherwise unlikely because of the following: (1) the associated calciturbidites contain detrital volcanic grains pointing to relatively local volcanism; (2) the tuffaceous sediments in the Tauride autochthon in the west (Sultan Dağ) include minor volcanic extrusives that must be in situ (Göncüoğlu et al. 2007); (3) seamounts including the one emplaced within the Teke Dere melange are typically relatively quiescent, without large volumes of regionally dispersed volcanic ash in contrast to felsic arc volcanism (e.g. Fisher and Schmincke 1984).

The alkaline volcanism within the Tauride Çataloturan unit (c. 340-350 Ma; Late Tournaisian-Late Visean) is c. $10 \mathrm{Ma}$ older than the late Carboniferous (320-310 Ma) (Moscovian-Bashkirian) calc-alkaline granitic rocks within the Afyon zone (Candan et al. 2016; Ustaömer et al. 2020), and is also older than the late Carboniferous-Early Permian subduction-accretion, as inferred from the youngest detrital zircon ages from the sandstone turbidites of the Konya and Karaburun melanges (Löwen et al. 2017, 2020; Ustaömer et al. 2020). One explanation is that 'normal' rifting took place along the north-Gondwana margin during the Late Devonian-early Carboniferous related to slab-pull towards the Eurasian active margin (Fig. 13b). There was then a switch from extension to contraction during the mid-Carboniferous, which triggered the localized late Carboniferous melange accretion and arc magmatism along the north-Gondwana margin (Fig. 1cii). Based on comparative stratigraphic thickness, sedimentation rates and thus subsidence rates are inferred to have increased markedly within the northGondwana platform during the latest Carboniferous (c. $300 \mathrm{Ma}$ ), based on evidence from the eastern Tauride autochthon (Geyik Dağ) (Göncüoğlu et al. 2004). Similar subsidence affected the central-Tauride Bolkar and Hadim (Aladağ) nappes (Mackintosh and Robertson 2012a). A possible cause of increased subsidence rate could be flexural loading related to regional suturing of Palaeotethys to the west of Turkey.

\section{Conclusions}

- Early Carboniferous (Late Tournaisian-Late Visean; c. 340-350 Ma) tuffaceous sediments, and rarely volcanics, are widely distributed along the northern margin of Gondwana, within both relatively autochthonous (Sul$\tan$ Dağ) and allochthonous (Aladağ) Tauride units.

- Chemical analysis of tuffaceous sediments from the early Carboniferous Çataloturan thrust sheet in the eastern Taurides (Aladağ unit) shows that they represent bimodal alkaline-type volcanism, with variable admixtures of terrigenous and siliceous biogenic material (radiolarians).

- Late Palaeozoic meta-basalts from the Binboğa metamorphic unit, part of the regional Malatya-Keban metamorphics (E Taurides) are interpreted to represent within-plate (extensional) volcanism within a shallowwater carbonate platform.

- Small outcrops of Late Palaeozoic or early Carboniferous basalts within the eastern Tauride autochthon (Feke unit) are likely to represent a southerly extension of the intra-plate volcanism.

- The patchy subduction signature (negative $\mathrm{Nb}$ and $\mathrm{Ta}$ anomalies) in both the Binboğa meta-volcanic rocks and the unmetamorphosed eastern Tauride autochthon (Feke unit) is likely to have been derived by melting of sub-continental mantle lithosphere (NeoproterozoicCambrian), combined with continental crust 'contamination' and variable fractionation, rather than coeval back-arc volcanism because evidence of a related arc is lacking.

- The combined sedimentary and igneous data suggest the presence of a relatively deep-water rift (Çataloturan unit) and a shallow-water zone of extension (Binboğa metamorphics) along the northern margin of Gondwana during the Late Palaeozoic.

- The early Carboniferous alkaline tuffs of the Çataloturan unit accumulated in a deep-water basin, within 
a carbonate platform that fringed the north margin of Gondwana, with an open-marine connection to Palaeotethys to the north, which allowed siliceous plankton (radiolarian) productivity.

- Regional comparisons suggest that the alkaline volcanism of the Çataloturan unit predated the regional late Carboniferous accretionary melanges of the Konya Complex (Afyon zone), the Teke Dere unit (Lycian nappes) and the Karaburan-Chios melange, and also the 320-310 Ma (Moscovian-Bashkirian)-aged granitic magmatism within the western Afyon zone (Anatolides).

- In the light of the regional closure history of the Variscan orogen, late Carboniferous melange accretion and arc magmatism could relate to relatively localized, short-lived subduction beneath Gondwana (Afyon zone). This assumes that the Anatolides remained as part of north-Gondwana. Otherwise, Palaeotethys subducted northwards beneath Eurasia during the Carboniferous-Late Triassic, and was progressively replaced by the İzmir-Ankara-Erzincan ocean (northern Neotethys) related to rifting of the north-Gondwana margin during the Triassic.

Acknowledgements We thank the DARIUS project for financial support to carry out the fieldwork in the eastern Taurides (2012-2013) and for covering the cost of the chemical analysis. Yağız Demirtay kindly assisted with diagram preparation. The first author's research (AHFR) on the Carboniferous melange and turbidites was assisted by the John Dixon memorial fund. The second author's research (OP) benefitted from on-going support from the State Key Lab for GPMR Open fund (GPMR201702) at CUG, and NSFC 91755213. The third author's research on the Carboniferous and Triassic units of the central Taurides and the Karaburun Peninsula (TU) was aided by TÜBİTAK research grants (Nos. 111R015 and 115Y213). The manuscript benefitted from constructive reviews by Prof. Dov Avigad and Prof. O. Candan.

Author contributions No declaration is preferred.

Availability of data and materials The chemical data are available from the first author on request.

Code availability Not relevant.

\section{Declarations}

Conflict of interest The authors have none.

Open Access This article is licensed under a Creative Commons Attribution 4.0 International License, which permits use, sharing, adaptation, distribution and reproduction in any medium or format, as long as you give appropriate credit to the original author(s) and the source, provide a link to the Creative Commons licence, and indicate if changes were made. The images or other third party material in this article are included in the article's Creative Commons licence, unless indicated otherwise in a credit line to the material. If material is not included in the article's Creative Commons licence and your intended use is not permitted by statutory regulation or exceeds the permitted use, you will need to obtain permission directly from the copyright holder. To view a copy of this licence, visit http://creativecommons.org/licenses/by/4.0/.

\section{References}

Adamia SH, Lebanidze Z, Svanidze TS, Shavishvili I (2003) Late Palaeozoic-Triassic geodynamic evolution of Georgia (Caucasus). Boll Soc Geol Ital 2:213-218

Adamia SH, Alania V, Chabukiani A, Kutelia Z, Sadradze N (2011) Great Caucasus (Cavcasioni): a long-lived north-Tethyan backarc basin. Turk J Earth Sci 20:611-628

Akal C, Candan O, Koralay OE, Oberhansli R, Chen F, Prelevic D (2012) Early Triassic potassic volcanism in the Afyon Zone of the Anatolides/Turkey: implications for the rifting of the NeoTethys. Int J Earth Sci 101:177-194

Aksay A (1980) A Lower Carboniferous sequence defined by a distinctive facies in the Taurus mountains (Aladağ region). Bull Geol Soc Turkey 23:193-199 (in Turkish with English abstract)

Alan İ, Şahin S, Keskin H, Altun İ, Bakırhan B, Balcı V, Böke N, Saçlı L, Pehlivan Ş, Kop A, Hanilçi N, Çelik ÖF (2007) Geodynamic evolution of central Tauride-Ereğli (Konya)-Ulukışla (Niğde)-Karsantı (Adana)-Namrun (İçel) region. General Directorate of Min Res Exp Report, vol 11006, pp 245 (unpublished, in Turkish)

Ayhan A, Lengeranl1 Y (1986) Tectonostratigraphical features of Aladağ region between Yahyalı and Demirkazık. Jeol Müh Der 27:31-45 (in Turkish)

Aysal N, Ustaömer T, Öngen S, Keskin M, Köksal F, Peytcheva I, Fanning M (2012) Origin of the Lower-Middle Devonian magmatism in the Sakarya Zone, NW Turkey: geochronology, geochemistry and isotope systematics. J Asian Earth Sci 45:201-222

Aysal N, Şahin SY, Güngör Y, Peytcheca I, Öngen S (2018) Middle Permian-early Triassic magmatism in the Western Pontides, NW Turkey: geodynamic significance for the evolution of the Paleo-Tethys. J Asian Earth Sci 164:83-103

Balc1 V (2010) 1/100.000 scale Turkish Geological Maps, Adana-M 34. Quadrangle, No: 142. Publ General Directorate Min Res Exp, p 30 (in Turkish with English abstract)

Barrier E, Vrielynck B, Brouillet JF, Brunet MF (2018) Paleotectonic reconstruction of the Central Tethyan Realm. Tectonosedimentary-Palinspastic maps from Late Permian to Pliocene. CCGM/CGMW, Paris, Atlas of 20 maps (scale: 1/15.000.000)

Bedi Y, Yusufoğlu H (2018) 1:000,000 scale Turkish Geological Map Series. Malatya-L49 Paftası. Publ General Directorate Min Res Exp, vol 261 (in Turkish)

Bedi Y, Yusufoğlu H, Beyazpirinç M, Özkan MK, Usta D, Yıldız H (2009) Geodynamical evolution of the Eastern Taurides (Afşin-Elbistan-Göksun-Sarız areas). General Directorate Min Res Exp Report, vol 11150, p 388 (in Turkish)

Bedi Y, Yusufoğlu H, Usta D, Okuyucu C (2012) The presence of the Alada $\breve{g}$ and Yahyalı Nappes in the Eastern Taurides (AfşinMalatya) and their tectonostratigraphic characteristics. In: Paleozoic of Northern Gondwana and its petroleum potential a field workshop, Sept. 9th Eur Assoc Geosci Eng, pp cp-367

Bernoulli D, Jenkyns HC (1974) Alpine, Mediterranean and central Atlantic Mesozoic facies in relation to the early evolution of the Tethys. In: Dott Jr RH, Shaver RH (eds) Modern and ancient geosynclinal sedimentation, vol 19. Spec Publ Soc Econ Paleontol Mineral, pp 129-160 
Blumenthal MM (1952) Geographical, Stratigraphical and Tectonical Features of the High Aladağ Mountains. Publ Min Res Exp Inst (MTA), Turkey, vol D6 (in German)

Bonev N, Filipov P, Raicheva R, Moritz R (2019) Timing and tectonic significance of Paleozoic magmatism in the Sakar unit of the Sakar-Strandzha Zone, SE Bulgaria. Int Geol Rev 61:1957-1979

Bozkaya Ö, Yalçın H, Başıüyük Z, Özfırat O, Yılmaz H (2007) Origin and evolution of the southeast Anatolian metamorphic complex (Turkey). Geol Carpath 58(3):197-210

Candan O, Çetinkaplan R, Oberhänsli RG, Akal C (2005) Alpine high$\mathrm{P} /$ low-T meta-morphism of the Afyon Zone and implications for the metamorphic evolution of western Anatolia, Turkey. Lithos $84: 102-124$

Candan O, Akal C, Koralay OE, Okay AI, Oberhänsli R, Prelević D, Mertz-Kraus R (2016) Carboniferous granites on the northern margin of Gondwana, Anatolide-Tauride Block, Turkey-evidence for southward subduction of Paleotethys. Tectonophysics 683:349-366

Chen G, Robertson AHF (2020) User's guide to the interpretation of sandstones using whole-rock chemical data, exemplified by sandstones from Triassic to Miocene passive and active margin settings from the Southern Neotethys in Cyprus. Sediment Geol 400:105616. https://doi.org/10.1016/j.sedgeo.2020.105616

Çimen O (2018) The new findings on the Late Devonian volcanism in the Eastern Taurides (Develi, Kayseri): preliminary data. Geol Bull Turkey 61:75-90

Cocks LRM, Torsvik TH (2006) European geography in a global context from the Vendian to the end of the Palaeozoic. In: Gee DG, Stephenson RA (eds) European lithosphere dynamics, vol 32. Geol Soc Lond Mem, pp 83-95

Cohen KM, Harper DAT, Gibbard PL (2020) ICS International Chronostratigraphic Chart, 2020/01. International Commission on Stratigraphy, IUGS, http://www.stratigraphy.org

Collins A, Robertson AHF (1998) Processes of Late Cretaceous to Late Miocene episodic thrust-sheet translation in the Lycian Taurides, southwestern Turkey. J Geol Soc Lond 155:759-772

Collins AS, Robertson AHF (1999) Evolution of the Lycian Allochthon, western Turkey, as a north-facing Late Palaeozoic to Mesozoic rift and passive continental margin. Geol J 34:107-138

Condie KC (1993) Chemical composition and evolution of the upper continental crust: contrasting results from surface samples and shales. Chem Geol 104:1-37

Dalkılıç H (2009) Türkiye Jeoloji Haritaları, 1:100.000 ölçekli Kayseri-L35 Paftası. Publ General Directorate Min Res Exp, vol 124 (in Turkish)

De Graciansky PC (1972) Récherches géologiques dans le Taurus Lycien Occidental, Dissertation, Université de Paris-sud, Centre d'Orsay

Demirtaşlı E (1967) Petroleum potential and lithostratigraphical units around Pınarbaş1-Sarız-Mağara regions. General Directorate Min Res Exp report, vol 6305 (in Turkish, unpublished)

Demirtaşlı E, Turhan N, Bilgin AZ, Selim M (1984) Geology of the Bolkar Mountains. In: Tekeli O, Göncüoğlu MC (eds), Geology of the Taurus Belt. Proc Int Symp Geology of the Taurus Belt, Ankara, Turkey, General Directorate Min Res Exp, pp 12-141

Dokuz A, Uysal İ, Kaliwoda M, Karslı O, Ottley CJ, Kandemir R (2011) Early abyssal- and late SSZ-type vestiges of the Rheic oceanic mantle in the Variscan basement of the Sakarya Zone, NE Turkey: implications for the sense of subduction and opening of the Paleotethys. Lithos 127:176-191

Dokuz A, Külekçi E, Aydınçakır E, Kandemir R, Alçiçek MC, Pecha ME, Sünnetçi K (2015) Cordierite-bearing strongly peraluminous
Cebre Rhyolite from the eastern Sakarya Zone, NE Turkey: constraints on the Variscan Orogeny. Lithos 278-281:285-302

Eren Y (1993) Stratigraphy of autochthonous and cover units of the Bozdağları massif, NW Konya. Geol Bull Turkey 36:7-23 (in Turkish with an English abstract)

Eren Y (1996) Structural features of the Bozdağlar massif to the south of Ilgın and Sarayönü (Konya). Geol Bull Turkey 39(2):49-64 (in Turkish with English abstract)

Eren Y, Kurt H (2000) The stratigraphical, geochemical and geodynamical modelling of the northeast margin of Menderes-Taurus Block. J Fac Eng Archit Selçuk Univ Konya 15(1):25-41 (in Turkish with an English abstract)

Eren Y, Kurt H, Rosselet F, Stampfli G (2004) Palaeozoic deformation and magmatism in the northern area of the Anatolide block (Konya), witness of the Palaeotethys active margin. Eclogae Geol Helv 97:293-306

Fisher RV, Schmincke H-U (1984) Pyroclastic rocks. Springer, Berlin, p 472

Fitton JG (2007) The OIB paradox. In: Foulger GR, Jurdy DM (eds) Plates, plumes, and planetary processes, vol 430. Geol S Am S, pp 387-412

Fitton JG, James D, Leeman WP (1991) Basic magmatism associated with the late Cenozoic extension in the western United States: compositional variation in space and time. J Geophys Res 96:13693-13711

Floyd PA, Winchester JA (1975) Magma type and tectonic setting discrimination using immobile elements. Earth Planet Sci Lett 27:211-218

Floyd PA, Winchester JA (1978) Identification and discrimination of altered and metamorphosed volcanic rocks using immobile elements. Chem Geol 21:291-306

Gharaire MHM, Matsumoto R, Kakuwa Y, Milroy PG (2004) Late Devonian facies variety in Iran: volcanism as a possible trigger of the environmental perturbation near the Frasnian-Famennian boundary. Geol Q 48:323-332

Gibson SA, Thompson RN, Leat PT, Morrison MA, Hendry GL, Dickin AP, Mitchell JG (1993) Ultrapotassic magmas along the flanks of the Oligo-Miocene Rio Grande Rift, USA: monitors of the zone of lithospheric mantle extension and thinning beneath a continental rift. J Petrol 34:187-228

Göncüoğlu MC (2011) Geology of the Kütahya-Bolkardağ Belt. Bull Min Res Exp 142:223-277

Göncüoğlu C, Kozur HW (1998) Remarks to the pre-Variscan development in Turkey. In: Linnemann U, Heuse T, Fatka O, Kraft P, Brocke R, Erdtmann B (eds) Pre-Variscan terrane analysis of Gondwanan Europe, Staatliche Naturhistorische Sammlungen Dresden, Musfür Min und Geol, Dresden, vol 9, pp 137-138

Göncüoğlu M, Turhan N, Şentürk K, Özcan A, Uysal S (2000) A geotraverse across NW Turkey: tectonic units of the Central Sakarya region and their tectonic evolution. In: Bozkurt E, Winchester JA, Piper JD (eds) Tectonics and magmatism in Turkey and the surrounding area, vol 173. Geol Soc Lond Spec Publ, pp 139-162

Göncüoğlu MC, Kozur H, Turhan N, Göncüoğlu Y (2001) Stratigraphy of the Silurian-Lower Carboniferous rock units in Konya area. I Congresso Iberico de Palaeontologia/XVI Jornades le la Sociedad Española de Palaeontologia, VII International Meeting IGCP 421, pp 227-228

Göncüoğlu MC, Turhan N, Tekin UK (2003) Evidence of Triassic rifting and opening of the Neotethyan İzmir-Ankara Ocean and discussion on the presence of Cimmerian events at the northern edge of the Tauride-Anatolide Platform, Turkey. Boll Soc Geol Ital Spec 2:203-212

Göncüoğlu MC, Göncüoğlu Y, Kozur HW, Kozlu H (2004) Paleozoic stratigraphy of the Geyik Dağ unit in the Eastern Taurides 
and implications for Gondwanian evolution. Geol Carpath 55:433-447

Göncüoğlu MC, Çapkınoğlu Ş, Gürsu S, Noble P, Turhan N, Tekin UK, Okuyucu C, Göncüoğlu Y (2007) The Mississippian in the Central and Eastern Taurides (Turkey): constraints on the tectonic setting of the Tauride-Anatolide Platform. Geol Carpath 58:427-442

Gromet LP, Dymek RF, Haskin LA, Korotev RL (1984) The "North American shale composite": its compilation, major and trace element characteristics. Geochim Cosmochim Acta 48:2469-2482

Gürsu S, Göncüoğlu MC (2005) Early Cambrian back-arc volcanism in the western Taurides, Turkey: implications for rifting along the northern Gondwanan margin. Geol Mag 142(617):631

Güven A, Ustaömer T, Peytcheva I (2012) Late Triassic crustal extension in NW Konya (Afyon Zone): New finding from LAICP-MS $\mathrm{U}-\mathrm{Pb}$ zircon dating of the Ladik dyke swarm and the Kadınhanı meta-volcanics. In: Proc 5th Geochem Symp, 23-25 May, Denizli, pp 122-123

Herron MM (1988) Geochemical classification of terrigenous sands and shales from core or log data. J Sediment Res 58:820-929

Hu Z, Gao S (2008) Upper crustal abundances of trace elements: a revision and update. Chem Geol 253:205-221

Iş1k A (1981) Foraminiferal biostratigraphy of the Nohutluktepe Lower Carboniferous succession (Aladağ region, E Taurides). Bull Geol Soc Turkey 24:79-84 (in Turkish with English abstract)

Karaoğlan F, Parlak O, Hejl E, Neubauer F, Klötzli U (2016) Temporal evolution of the active margin along the Southeast Anatolian Orogenic Belt (SE Turkey): evidence from U-Pb, $\mathrm{Ar}-\mathrm{Ar}$ and fission track chronology. Gondwana Res 33:190-208

Karslı O, Dokuz A, Kandemir R (2016) Subduction-related Late Carboniferous to early Permian magmatism in the Eastern Pontides, the Camlik and Casurluk plutons: insights from geochemistry, whole-rock $\mathrm{Sr}-\mathrm{Nd}$ and in situ zircon $\mathrm{Lu}-\mathrm{Hf}$ isotopes, and $\mathrm{U}-\mathrm{Pb}$ geochronology. Lithos 266-267:98-114

Karslı O, Şengün F, Dokuz AR, Aydın F, Anderson T (2020) Silurian to Early Devonian arc magmatism in the western Sakarya Zone (NW Turkey), with inference to the closure of the Rheic Ocean. Lithos. https://doi.org/10.1016/j.lithos.2020.105641

Kaya A (2016) Tectono-stratigraphic reconstruction of the Keban metamorphites based on new fossil findings, Eastern Turkey. J Afr Earth Sci 124:245-257

Kelemen PB, Yogodzinski G M, Scholl D W (2003) Along-strike variation in the Aleutian island arc: genesis of high-Mg\# andesite and implications for continental crust. In: Eiler J (ed) Inside the Subduction Factory, vol 138. Geophys Monogr, Amer Geophys Un, pp 223-276

Kempton PD, Fitton JG, Hawkesworth CJ, Ormerod DS (1991) Isotopic and trace element constraints on the composition and evolution of the lithosphere beneath the southwestern United States. J Geophys Res 96:13713-13735

Kozur HW, Şenel M (1999) Carboniferous oceanic sequences in the Lycian nappes of southern Turkey. XIV ICCP, International Congress on the Carboniferous-Permian, Calgary, p 79

Kozur HW, Şenel M, Tekin K (1998) First evidence of Hercynian Lower Carboniferous deep-water sediments in the Lycian Nappes, SW Turkey. Geol Croatica 51:15-22

Kroner U, Romer RL (2013) Two plates-many subduction zones: the Variscan orogeny reconsidered. Gondwana Res 24:298-329

Kröner A, Şengör AMC (1990) Archean and Proterozoic ancestry in late Precambrian to early Paleozoic crustal elements of southern Turkey revealed by single-zircon dating. Geology 18:1186-1190

Kurt H (1996) Geochemical characteristics of the metaigneous rocks near Kadınhanı (Konya, Turkey). Geosound 28:1-22

Kurt H (1997) Geochemistry of metasedimentary rocks of the Kadınhanı (Konya) area, Turkey. Geosound 31:1-21
Lechler PJ, Desilets MO (1987) A review of the use of loss on ignition as a measurement of total volatiles in whole-rock analysis. Chem Geol 63:341-344

Linnemann U, Gerdes A, Drost K, Buschmann B (2007) The continuum between Cadomian orogenesis and opening of the Rheic Ocean: Constraints from LA-ICP-MS U-Pb zircon dating and analysis of plate-tectonic setting (Saxo-Thuringian zone, northeastern Bohemian Massif, Germany). In: Linnemann, U, Nance D, Kraft P, Zulauf G (eds) The evolution of the Rheic Ocean: from Avalonian-Cadomian active margin to Alleghenian-Variscan collision, vol 423. Geol Soc Am Special Paper, pp 61-96

Löwen K, Meinhold G, Güngör T, Berndt J (2017) Palaeotethysrelated sediments of the Karaburun Peninsula, western Turkey: constraints on provenance and stratigraphy from detrital zircon geochronology. Int J Earth Sci 106:2771-2796

Löwen K, Meinhold G, Arslan A, Güngör T, Berndt J (2020) Evolution of the Paleotethys in the Eastern Mediterranean: a multi-method approach to unravel the age, provenance and tectonic setting of the Upper Paleozoic Konya Complex and its Mesozoic cover sequence (south-central Turkey). Int Geol Rev 62:389-414

Lytwyn JN, Casey JF (1995) The geochemistry of post-kinematic mafic dyke swarms and subophiolitic metabasites, Pozant1-Karsant1 ophiolite, Turkey: evidence for ridge subduction. Geol Soc Am Bull 107:830-850

Mackintosh PW, Robertson AHF (2012a) Late Devonian-Late Triassic sedimentary development of the central Taurides, S Turkey: implications for the northern margin of Gondwana. Gondwana Res 21:1089-1114

Mackintosh PW, Robertson AHF (2012b) Sedimentary and structural evidence for two-phase Upper Cretaceous and Eocene emplacement of the Tauride thrust sheets in central southern Turkey. In: Robertson AHF, Parlak O, Ünlügenç UC (eds) Geological development of Anatolia and the Easternmost Mediterranean Region, vol 372. Geol Soc Lond Spec Publ, pp 299-322

McLennan SM, Taylor SR (1984) Archaean sedimentary rocks and their relation to the composition of the Archaean continental crust. In: Kröner A, Hanson GN, Goodwin AM (eds) Archaean Geochemistry: the origin and evolution of the Archaean Continental Crust. Springer, Berlin, pp 47-72

McLennan SM, Hemming S, McDaniel D, Hanson G (1993) Geochemical approaches to sedimentation, provenance, and tectonics. In: Johnsson, MJ, Basu A (eds) Processes controlling the composition of clastic Sediments, vol 284. Geol Soc Am Special Paper, pp 21-40

Meinhold G, Reischmann T, Kostopoulos D, Lehnert O, Matukov D, Sergeev S (2008) Provenance of sediments during subduction of Palaeotethys: detrital zircon ages and olistolith analysis in Palaeozoic sediments from Chios Island, Greece. Palaeogeogr Palaeoclimatol Palaeoecol 263:71-91

Metin S (1983) Geology of Derebaş1 (Develi), Armutalan and Gedikli (Saimbeyli) towns in the Eastern Taurides. PhD thesis, İstanbul Universitesi (in Turkish)

Metin S (1986) Geology of Bakırdağı and surroundings in the Eastern Taurides. General Directorate Min Res Exp report, vol 7888, Ankara (in Turkish)

Moix P, Beccaletto L, Kozur HW, Hochard C, Rosseleti F, Stampfli GM (2008) New classification of the Turkish terranes and sutures and its implication for the paleotectonic history of the region. Tectonophysics 451:7-39

Moix P, Vachard D, Allibon J, Martini R, Wernli R, Kozur HW, Stampfli GM (2013) Palaeotethyan, Neotethyan and HuğluPindos series in the Lycian Nappes (SW Turkey): geodynamical implications. In: Tanner LH, Spielmann JA, Lucas SG (eds) The Triassic System, vol 61. New Mexico Mus Nat Hist Sci, pp 401-444 
MTA (2011) Geological map of Turkey 1:250,000 (Maden Tektik ve Arama Genel Müdürlüğü (General Directorate of Min Res Exp), Ankara

Nesbitt HW, Young G (1984) Prediction of some weathering trends of plutonic and volcanic rocks based on thermodynamic and kinetic considerations. Geochim Cosmochim Acta 48:1523-2153

Okay AI, Topuz G (2017) Variscan orogeny in the Black Sea region. Int J Earth Sci (Geol Rundsch) 106:569-592. https://doi.org/10. 1007/s00531-016-1395-z

Okay AI, Satır M, Maluski H, Siyako M, Monie P, Metzger R, Akyüz S (1996) Paleo- and Neo-Tethyan events in northwestern Turkey: geologic and geochronologic constraints. In: Yin A, Harrison TM (eds) The tectonic evolution of Asia. Cambridge University Press, Cambridge, pp 420-441

Okay AI, Satır M, Siebel W (2006) Pre-Alpide Palaeozoic and Mesozoic orogenic events in the Eastern Mediterranean region. In: Gee D G, Stepherson RA (eds) European Lithosphere dynamics, vol 32. Geol Soc Lond Mem, pp 389-406

Okay AI, Satır M, Shang CK (2008) Ordovician metagranite from the Anatolide-Tauride Block, north-west Turkey-geodynamic implications. Terra Nova 20:280-288

Okuyucu C, Vachard D (2006) Late Viséan foraminifers and algae from the Cataloturan Nappe, Alada $\breve{g}$ Mountains, eastern Taurides, southern Turkey. Geobios 39:535-555

Özbey Z, Ustaömer T, Robertson AHF, Ustaömer PA (2013) Tectonic significance of Late Ordovician granitic magmatism and clastic sedimentation on the northern margin of Gondwana (Tavşanlı Zone, NWTurkey). J Geol Soc Lond 170:159-173

Özcan A, Göncüoğlu MC, Turhan N, Uysal S, Şentürk K, Işık A (1988) Late Palaeozoic evolution of the Kütahaya-Bolkardağ Belt. METU J Pure Appl Sci 21:211-220

Özcan A, Göncüoğlu MC, Turhan N, Uysal S, Işık A, Şentürk K (1990) Basic geology of the Konya-Kadınhanı-Ilgın and adjacent areas. General Directorate Min Res Exp Report, vol 9535, Ankara (in Turkish)

Özdamar Ş, Billor MZ, Sunal G, Esenli F, Roden MF (2013) First U-Pb SHRIMP zircon and ${ }^{40} \mathrm{Ar} /{ }^{39} \mathrm{Ar}$ ages of metarhyolites from the Afyon-Bolkardag Zone, SW Turkey: implications for the rifting and closure of the Neo-Tethys. Gondwana Res 24:377-391

Özgül N (1984) Stratigraphy and tectonic evolution of the central Taurides. In: Tekeli O, Göncüoğlu MC (eds) In: Proc Geology of the Taurus Belt. General Directorate Min Res Exp, Ankara, pp 77-90

Özgül N (1997) Stratigraphy of the tectono-stratigraphic units in the region Bozkır-Hadim-Taşkent (northern central Taurides) (in Turkish). Bull Min Res Exp 119:113-174 (in Turkish)

Özgül N, Kozlu H (2002) Data on the stratigraphy and tectonics of the Kozan-Feke region (Eastern Taurides). Turk Ass Petrol Geol Bull 14:1-36

Pamić J, Jurković I (2002) Paleozoic tectonostratigraphic units of the northwest and central Dinarides and the adjoining South Tisia. Int J Earth Sci 91:538-554

Papanikolaou D, Sideris C (1983) Le Paléozoïque de l'autochtone de Chios: une formation à bloc de type wildflysch d'âge Permien (pré parte). Comptes Rendus De L'académie Des Sciences 297:603-606

Parlak O (2006) Geodynamic significance of granitoid magmatism in the southeast Anatolian orogen: geochemical and geochronogical evidence from Göksun-Afşin (Kahramanmaraş, Turkey) region. Int J Earth Sci 95:609-627

Parlak O, Robertson AHF (2004) The ophiolite-related Mersin Melange, southern Turkey: its role in the tectonic-sedimentary setting of Tethys in the Eastern Mediterranean region. Geol Mag 141:257-286

Parlak O, Höck V, Delaloye M (2000) Suprasubduction zone origin of the Pozant1-Karsant1 ophiolite (southern Turkey) deduced from whole rock and mineral chemistry of the gabbroic cumulates. In:
Bozkurt E, Winchester JA, Piper JD (eds) Tectonics and magmatism in Turkey and the surrounding area, vol 173. Geol Soc Lond, Spec Publ, pp 219-234

Pearce JA (1982) Trace element characteristics of lavas from destructive plate boundaries. In: Thorpe RS (ed) Andesites. Wiley, New York, pp 525-548

Pearce JA (1983) Role of the sub-continental lithosphere in magma genesis at active continental margins. In: Hawkesworth CJ, Norry MJ (eds) Continental Basalts and Mantle Xenoliths. Cheshire, Shiva Publications, Nantwich, pp 230-249

Pearce JA (1996) A users guide to basalt discrimination diagrams. In: Wyman DA (ed) Trace element geochemistry of volcanic rocks: applications for massive sulphide exploration. Geohemistry Short Course Notes, Geol Assoc Can, pp 79-113

Pearce JA, Cann JR (1973) Tectonic setting of basaltic volcanic rocks determined using trace element analysis. Earth Planet Sci Lett 19:290-300

Pearce JA, Norry MJ (1979) Petrogenetic implications of Ti, Zr, Y, and $\mathrm{Nb}$ variations in volcanic rocks. Contrib Mineral Petrol 69:33-47

Pearce JA, Harris NBW, Tindle AG (1984) Trace element discrimination diagrams for the tectonic interpretation of granitic rocks. J Petrol 25:956-983

Perinçek D, Kozlu H (1984) Stratigraphical and structural relations of the units in the Afşin-Elbistan-Doğanşehir region (Eastern Taurus). In: Tekeli O, Göncüoğlu MC (eds) Proc geology of the Taurus Belt. General Directorate Min Res Exp, Ankara, pp 181-198

Pettijohn FJ, Potter PE, Siever R (1972) Sand and sandstone. Springer, New York

Pickett EA, Robertson AHF (1996) Formation of the Late Palaeozoic-Early Mesozoic Karakaya Complex and related ophiolites in NW Turkey by Paleotethyan subduction-accretion. J Geol Soc Lond 153:995-1009

Pik R, Marty B, Hilton DR (2006) How many mantle plumes in Africa? The geochemical point of view. Chem Geol 226:100-114

Polat A, Casey JF (1995) A structural record of the emplacement of the Pozantı-Karsantı ophiolite onto the Menderes-Taurus block in the Late Cretaceous, eastern Taurides, Turkey. J Struct Geol 17:1673-1688

Polat A, Casey JF, Kerrich R (1996) Geochemical characteristics of accreted material beneath the Pozant1-Karsant1 ophiolite, Turkey: intra-oceanic detachment, assembly and obduction. Tectonophysics 263:249-276

Pourteau A (2011) Closure of the Neotethys Ocean in Anatolia: structural, petrologic \& geochronologic insights from low-grade highpressure metasediments, Afyon Zone. PhD thesis, University of Potsdam, p 119

Pourteau A, Candan O, Oberhänsli R (2010) High-pressure metasediments in central Turkey: constraints on the Neotethyan closure history. Tectonics 29(TC5004):18p

Pourteau L, Sudo M, Candan O, Lanari P, Vidal O, Oberhänsli R (2013) Neotethys closure history of Anatolia: insights from ${ }^{40} \mathrm{Ar}-{ }^{39} \mathrm{Ar}$ geochronology and P-T estimation in high pressure metasedimentary rocks. J Metamorph Geol 31:585-606

Pourteau A, Oberhänsli R, Candan O, Barrier E, Vrielynck B (2016) Neotethyan closure history of western Anatolia: a geodynamic discussion. Int J Earth Sci 105:203-224

Rızaoğlu T, Parlak O, Hoeck V, Koller F, Hames WE, Billor Z (2009) Andean-type active margin formation in the eastern Taurides: geochemical and geochronogical evidence from the Baskil granitoid (Elazı $\breve{g}$, SE Turkey). Tectonophysics 473:188-207

Robertson AHF (2007) Evidence of continental breakup from the Newfoundland rifted margin (Ocean Drilling Program Leg 210): Lower Cretaceous seafloor formed by exhumation of subcontinental mantle lithosphere and the transition to seafloor spreading. In: Tucholke BE, Sibuet J-C, Klaus A (eds) Proc ODP Sci Res 
210, College Station, TX, Ocean Drilling Program, https://doi. org/10.2973/odp.proc.sr.210.104.2007

Robertson AHF, Dixon JE (1984) Introduction: Aspects of the geological evolution of the Eastern Mediterranean. In: Dixon JE, Robertson AHF (eds) The Geological Evolution of the Eastern Mediterranean, vol 17. Geol Soc Lond Spec Publ, pp 1-7

Robertson AHF, Pickett EA (2000) Palaeozoic-Early Tertiary Tethyan evolution of melanges, rift and passive margin units in the Karaburun Peninsula (western Turkey) and Chios Island (Greece). In: Bozkurt E, Winchester JA, Piper JD (eds) Geological evolution of Turkey and the Surrounding Area, vol 173. Geol Soc Lond Spec Publ, pp 25-42

Robertson AHF, Ustaömer T (2009a) Formation of the upper Palaeozoic Konya complex and comparable units in southern Turkey subduction-accretion processes: implications for the tectonic development of Tethys in the Eastern Mediterranean region. Tectonophysics 473:113-148

Robertson AHF, Ustaömer T (2009b) Upper Palaeozoic subduction/ accretion processes in the closure of Palaeotethys: evidence from the Chios Melange (E Greece), the Karaburun Melange (W Turkey) and the Teke Dere Unit (SW Turkey). Sediment Geol 220:9-59

Robertson AHF, Ustaömer T (2011) Role of tectonic-sedimentary melange and Permian-Triassic cover units, central southern Turkey in Tethyan continental margin evolution. J Asian Earth Sci 40:98-120

Robertson AHF, Ustaömer T, Pickett EA, Collins AS, Andrew T, Dixon JE (2004) Testing models of Late Palaeozoic-Early Mesozoic orogeny in Western Turkey. Support for an evolving open-Tethyan model. J Geol Soc Lond 161:501-511

Robertson AHF, Ustaömer T, Parlak O, Ünlügenç UC, Taslı K, İnan N (2006) The Berit transect of the Tauride thrust belt, S. Turkey: Late Cretaceous-Early Cenozoic accretionary/collisional processes related to closure of the southern Neotethys. J Asian Earth Sci 27:108-145

Robertson AHF, Parlak O, Ustaömer T (2009) Melange genesis and ophiolite emplacement related to subduction of the northern margin of the Tauride-Anatolide continent, central and western Turkey. In: Van Hinsbergen DJJ, Edwards MA, Govers R (eds) Collision and collapse at the Africa-Arabia-Eurasia Subduction Zone, vol 311. Geol Soc Lond Spec Publ, pp 9-66

Robertson AHF, Parlak O, Ustaömer T (2012) Overview of the Palaeozoic-Neogene evolution of Neotethys in the Eastern Mediterranean region (southern Turkey, Cyprus, Syria). Pet Geosci 18:381-404

Robertson AHF, Palak O, Ustaömer T (2013) Mesozoic-Early Cenozoic palaeogeographic development of Southern Turkey and the easternmost Mediterranean region: evidence from the inter-relations of continental and carbonate platform units. In: Robertson AHF, Parlak O, Ünlügenç UC (eds) Geological development of the Anatolian Continent and the Easternmost Mediterranean Basin, vol 372. Geol Soc Lond Spec Publ, pp 167-218

Robertson AHF, Parlak O, Kinnaird TC, Taslı K, Dumitrica P (2020) Cambrian-Eocene pre-rift, pulsed rift, passive margin and emplacement processes along the northern margin of the Southern Neotethys: evidence from the Antalya Complex in the Alanya Window (S Turkey). J Asian Earth Sci 3:100026. https://doi.org/ 10.1016/j.jaesx.2020.100026

Robertson AHF, Parlak O, Ustaömer T, Taslı K, Dumitrica P (2021a) Late Palaeozoic-Neogene sedimentary and tectonic development of the Tauride continent and adjacent Tethyan ocean basins in eastern Turkey: new data and integrated interpretation. J Asian Earth Sci. https://doi.org/10.1016/j.jseaes.2021.104859

Robertson AHF, Parlak O, Dumitrica P (2021b) Role of volcanic-sedimentary melanges, especially the Aladağ melange, in the riftdrift-subduction-accretion-emplacement history of the Mesozoic
Inner Tauride ocean. Int Geol Rev. https://doi.org/10.1080/00206 814.2021 .1925980

Rolland Y (2017) Caucasus collisional history: review of data from East Anatolia to West Iran. Gondwana Res 49:130-146

Rolland Y, Hässig M, Bosch D, Meijers MJM, Sosson M, Bruguier O, Adamia SH, Sadradze N (2016) A review of the plate convergence history of the East Anatolia-Transcaucasus region during the Variscan: insights from the Georgian basement and its connection to the Eastern Pontides. J Geodyn 96:131-145

Rollinson HR (1993) Using geochemical data: evaluation, presentation, interpretation. Routledge, London

Romano SS, Brix MR, Dörr W, Fiala J, Krenn E, Zulauf G (2006). The Carboniferous to Jurassic evolution of the pre-Alpine basement of Crete: constraints from radiometric dating of orthogneiss, fission-track dating of zircon and structural/petrological data. In: Robertson AHF, Mountrakis D (eds) Tectonic Development of the Eastern Mediterranean Region, vol 260. Geol Soc Lond Spec Pub, pp 69-90

Romer RL, Förster HJ, Breitkreuz C (2001) Intra-continental extensional magmatism with a subduction fingerprint: the Late Carboniferous Halle volcanic complex (Germany). Contrib Mineral Petrol 14:201-221

Rudnick RL, Gao S (2003) Composition of the continental crust. In: Holland HD, Turekian KK (eds) Treatise on geochemistry, vol 3. Elsevier-Pergamon, Oxford, pp 1-64

Ruttner AW (1991) Geology of the Aghdarband area (Kopetdagh, NEIran) (with contributions of R Brander and E Kirchner). Abh Geol Bundesanstalt 38:7-79

Sdrolias M, Müller RD (2006) Controls on back-arc basin formation. Geochem Geophys Geosyst 7:Q04016. https://doi.org/10.1029/ 2005GC001090

Şenel YM, Şelçuk H, Bilgin ZR, Sen AM, Karaman T, Dinçer MA, Durukan E, Arbas A, Örçen S, Bilgi C (1989) Cameli (Denizli)_Yeşilova (Burdur) -Elmalı (Antalya) ve Doloyının Jeolojisi. General Directorate Min Res Exp report, vol 9429, Ankara (in Turkish)

Şengör AMC, Yılmaz Y (1981) Tethyan Evolution of Turkey: a plate tectonic approach. Tectonophysics 75:181-241

Şengör A, Y1lmaz Y, Sungurlu O (1984) Tectonics of the Mediterranean Cimmerides: nature and evolution of the western termination of Palaeo-Tethys. In: Dixon JE, Robertson AHF (eds) The geological evolution of the Eastern Mediterranean, vol 17. Geol Soc Lond Spec Publ, pp 77-112

Stampfli GM, Borel GD (2002) A plate tectonic model for the Paleozoic and Mesozoic constrained by dynamic plate boundaries and restored synthetic oceanic isochrons. Earth Planet Sci Lett 196:17-33

Stampfli GM, Kozur HW (2006) Europe from the Variscan to the Alpine cycles. In: Gee DG, Stepherson RA (eds) European Lithosphere Dynamics, vol 32. Geol Soc Lond Mem, pp 43-56

Stampfli GM, Mosar P, Faure A, Vannay JC (2001) Permo-Mesozoic evolution of the western Tethys realm: the Neotethys East Mediterranean basin connection. In: Ziegler P, Cavazza W, Robertson AHF, Crasquin-Soleau S (eds) Peri-Tethys Memoir 5, Peri-Tethyan Rift/Wrench Basins and Passive Margins, vol 5. Mem Mus Nat Hist Nat, pp 1-108

Stampfli GM, Hochard C, Verard C, Vilhem C, von Raumer J (2013) The formation of Pangea. Tectonophysics 593:1-19

Sun SS, McDonough WF (1989) Chemical and isotopic systematics of oceanic basalts: implications for mantle composition and processes. In: Saunders AD, Norry MJ (eds) Magmatism in the Ocean Basins, vol 42. Geol Soc Lond Spec Publ, pp 313-345

Sunal G (2012) Devonian magmatism in the western Sakarya Zone Karacabey Region, NW Turkey. Geodin Acta 25:183-201

Taylor SR, McLennan SM (1985) The continental crust: its composition and evolution. Blackwell Scientific Publications, Hoboken 
Tekeli O (1981) The characteristic features of the Aladağ ophiolitic melange (Taurus Mountains). Bull Geol Soc Turkey 24:57-63 (in Turkish with an English summary)

Tekeli O, Aksay A, Ürgün BM, Işık A (1984) Geology of the Aladă Mountains. In: Tekeli O, Güncüoğlu MC (eds) Geology of the Taurus Belt. IN: Proc Int Symp 26-29 September 1983, Ankara, Turkey, pp 143-158

Topuz G, Altherr R, Siebel W, Schwarz WH, Zack T, Hasözbek A, Barth M, Satır M, Şen C (2010) Carboniferous high potassium I-type granitoid magmatism in the Eastern Pontides: the Gumus , hane pluton (NE Turkey). Lithos 116:92-110

Topuz G, Candan O, Okay AI, von Quadt A, Othman M, Zack T, Wang J (2019) Silurian anorogenic basic and acidic magmatism in Northwest Turkey: Implications for the opening of the PaleoTethys. Lithos 356-357:105302. https://doi.org/10.1016/j.lithos. 2019.105302

Uğurcan OG, Ustaömer T, Gerdes A (2019) Cambrian-Early Ordovician magmatism, Mid-Late Palaeozoic sedimentation and Early Caboniferous metamorphism in the Central Sakarya Terrane, Sakarya Zone, NW Turkey. International Earth Science Colloquium on the Aegean Region (IESCA), 7-11 October 2019, İzmir, $\mathrm{p} 11$

Ünlügenç UC, Demirkol, C (1991) Stratigraphy of Karsant1-AkdamEğner (N-NE Adana) region. In: Yetiş C (ed) Proc Ahmet Acar Geol Symp, Adana, pp 239-254

Ustaömer T, Robertson AHF (1993) A Late Palaeozoic-Early Mesozoic marginal basin along the active southern continental margin of Eurasia: Evidence from the Central Pontides (Turkey) and adjacent regions. Geol J 28:219-238

Ustaömer T, Robertson A H F (1997) Tectonic-sedimentary evolution of the north Tethyan margin in the Central Pontides of northern Turkey. In: Robinson AG (ed) Regional and Petroleum Geology of the Black Sea and Surrounding Region, vol 68, pp 255-290.

Ustaömer PA, Ustaömer T, Robertson AHF (2012) Ion probe U-Pb dating of the Central Sakarya basement: a Peri-Gondwana Terrane cut by late Lower Carboniferous subduction/collision-related granitic magmatism. Turk J Earth Sci 21:905-932

Ustaömer T, Robertson AHF, Ustaömer PA, Gerdes A, Peytcheva I (2013) Constraints on Variscan and Cimmerian magmatism and metamorphism in the Pontides (Yusufeli-Artvin area), NE Turkey from $\mathrm{U}-\mathrm{Pb}$ dating and granite geochemistry. In: Robertson AHF, Parlak O, Ünlügenç UC (eds) Geological development of Anatolia and the Easternmost Mediterranean Region, vol 372. Geol Soc Lond Spec Publ, pp 49-74

Ustaömer T, Ustaömer PA, Robertson AHF, Gerdes A (2016a) Implications of $\mathrm{U}-\mathrm{Pb}$ and $\mathrm{Lu}-\mathrm{Hf}$ isotopic analysis of detrital zircons for the depositional age, provenance and tectonic setting of the Permian-Triassic Palaeotethyan Karakaya Complex, NW Turkey. Int J Earth Sci 105:7-38

Ustaömer T, Ustaömer PA, Robertson AHF, Gerdes A (2016b) Testing alternative tectonic models of Palaeotethys in the E Mediterranean region: New $\mathrm{U}-\mathrm{Pb}$ and $\mathrm{Lu}-\mathrm{Hf}$ isotopic analyses of detrital zircons from Late Carboniferous and Late Triassic sandstones associated with the Anatolide and Tauride blocks (S Turkey), vol 18. Geophys Res Abstracts, pp EGU2016-15469-1

Ustaömer T, Ustaömer PA, Robertson AHF, Gerdes A (2020) U-Pb$\mathrm{Hf}$ isotopic data from detrital zircons in late Carboniferous and
Mid-Late Triassic sandstones, and also Carboniferous granites from the Tauride and Anatolide continental units in S Turkey: implications for Tethyan palaeogeography. Int Geol Rev 62:1159-1186

Vachard D, Moix P (2011) Late Pennsylvanian to Middle Permian revised biostratigraphy and palaeobiogeography of the Lycian Nappes (SW Turkey). Revue Micropaleontol 54:141-174

Vai GB (2003) Development of the palaeogeography of Pangaea from late Carboniferous to early Permian. Palaeogeog Palaeoclimatol Palaeoecol 196:125-155

van Hinsbergen DJJ, Torsvig TH, Schmid SM, Matenco LC, Maffione M, Vissers LM, Gürer D, Spakman W (2020) Orogenic architecture of the Mediterranean region and kinematic reconstruction of its tectonic evolution since the Triassic. Gondwana Res 81:79-22

Verma SP (2009) Continental rift setting for the central part of the Mexican Volcanic Belt: a statistical approach. Open Geol J 3:8-29

von Raumer JF, Stampfli GM, Bussy F (2003) Gondwana-derived microcontinents - the constituents of the Variscan and Alpine collisional orogens. Tectonophysics 365:7-22

Wendt J, Kaufmann B, Belka Z, Farsan N, Karimi Bavandpour A (2002) Devonian/Lower Carboniferous stratigraphy, facies patterns and palaeogeography of Iran, part I, northern and southeastern Iran. Acta Geol Pol 52(2):129-168

Wu L, Murphy JB, Quesada C, Zheng-Xiani Z-X, Waldron JWF, Williams S, Pisarevsky S, Collins WJ (2020) The amalgamation of Pangea: paleomagnetic and geological observations revisited. Geol Soc Am Bull. https://doi.org/10.1130/B35633.1

Zanchi A, Garzanti E, Larghi C, Angiolini L (2003) The Variscan orogeny in Chios (Greece): Carboniferous accretion along a Palaeotethyan active margin. Terra Nova 15:213-223

Zlatkin O, Avigad D, Gerdes A (2013) Evolution and provenance of Neoproterozoic basement and lower Paleozoic siliciclastic cover of the Menderes Massif (western Taurides): Coupled U-Pb-Hf zircon isotope geochemistry. Gondwana Res 23:682-700

Zulauf G, Blau J, Dörr W, Klein T, Krahl J, Kustatscher E, Petschick R, van de Schootbrugge B (2013) New U-Pb zircon and biostratigraphic data of the Tyros Unit, eastern Crete: constraints on Triassic palaeogeography and depositional environment of the eastern Mediterranean. Z Dtsch Ges Für Geowissenschaften $164: 337-352$

Zulauf G, Dörr W, Fisher-Spurlock S, Gerdes A, Chatzaras V, Xypolias P (2015) Closure of the Paleotethys in the External Hellenides: constraints from $\mathrm{U}-\mathrm{Pb}$ ages of magmatic and detrital zircons (Crete). Gondwana Res 28:642-667

Zulauf G, Dörr W, Krahl J, Lahaye Y, Chatzaras V, Xypolias P (2016) U-Pb zircon and biostratigraphic data of high-pressure/ low-temperature metamorphic rocks of the Talea Ori: tracking the Paleotethys suture in central Crete, Greece. Int J Earth Sci 105:1901-1922

Zulauf G, Dörr W, Marko L, Krahl J (2018) The late Eo-Cimmerian evolution of the external Hellenides: constraints from microfabrics and U-Pb detrital zircon ages of Upper Triassic (meta) sediments (Crete, Greece). Int J Earth Sci 107:2859-2894 